\title{
PROSPECTS FOR AGRICULTURAL PRODUCTIVITY GROWTH: WILL THERE BE A SLOWDOWN IN DEVELOPING COUNTRIES? ${ }^{1}$
}

\author{
Jenifer Piesse, Department of Management, King's College London \\ and Department of agricultural Economics, University of Stellenbosch, RSA
}

\section{Colin Thirtle, Centre for Environmental Policy, Imperial College London and Department of Agricultural Economics, Extension and Development, University of Pretoria, RSA}

\begin{abstract}
The food price spikes of 2008 showed that world food security is not a foregone conclusion. With this in mind, we distinguish between three productivity measures, as their implications differ. These are: yields, which, with area harvested, determine output; labour productivity, which correlates with incomes; and total factor productivity, which distinguishes between technical progress, efficiency change and input intensification. Hence TFP growth has different implications, according to its cause.
\end{abstract}

The World Development Report (World Bank, 2008) distinguishes between the agriculture-based, transforming, and urbanised countries that constitute agriculture's three worlds. The first is dominated by Sub-Saharan Africa (SSA), with much of Asia and the Middle East and North Africa (MENA) region in the transitional group, while and urbanised developing economies are mostly in Eastern and Central Europe and Latin America. We would add the developed countries (DCs) that are loosely member states of the OECD.

The DCs are not the focus, but the slowing of public agricultural R\&D growth in this group, plus low rates of GDP growth and possibly agricultural productivity measures, have connotations for all the others, as these countries are the initial source of scientific advances and technologies. We find a tendency for yield and labour productivity growth to slow from the mid 1980s, but TFP did not slow down in all countries. What did happen more generally, is that TFP growth was maintained by input reduction, rather than output growth, as investment in agriculture declined due to lack of profitability. This is why the supply response in 2008 was rapid, but as it was achieved by increasing modern inputs, TFP will have been reduced, although yields should have risen. There is some consensus that new technology is not being generated as it once was, but here there is a gulf between North America, where private sector GM varieties have filled the gap and Europe where they have been largely excluded.

\footnotetext{
${ }^{1}$ This paper was written for the OECD/FAO Group on Commodity Markets Working Party on Agricultural Policies and Markets and presented at the OECD Conference Centre, Paris, 7 April 2009. We thank the OECD for funding the project and those attending the workshop for useful comments on the presentation.
} 
If there is less technology internationally available from the world's leading national agricultural research stations (NARS), the effect on the urbanised countries may not be great. The Eastern and Central European countries have to long way to go to increase efficiency levels to match Northern Europe, so reorganisation matters more than technical progress. In Latin America, countries like Brazil and Argentina are industrialising and commercialising agriculture and have their own research capacity that may well increase yields as a result. They are almost certain to increase labour productivity as agriculture is mechanised and TFP should be driven by labour productivity growth.

For the upper end of the transforming countries the same is true, as China and India have the research capacity to generate yield growth and the withdrawal of labour from agriculture will raise labour productivity and TFP. It is the smaller countries, with less research capacity and less industrialisation that may be at risk from productivity stagnation if they do not attract private technology providers.

The agriculture-based countries range from the small failed states of SSA to countries like Kenya, which has quite reasonable research capacity. All the TFP studies show that SSA lags behind, but that productivity has been improving since the mid 1980s. The key seems to be institutions, incentives and better policy and infrastructure. It is efficiency change, rather than new technology and SSA could have reasonable growth in TFP and yields on this basis alone. A major difference between Asia and Africa is that in Asia, yield growth has been translated into increased labour productivity and better incomes. In SSA, yield increases have improved labour productivity very little, so there is a difficult question as to whether the relatively land abundant countries can follow a path of labour saving technical change.

The unknowns that will determine the future course of agricultural development centre around energy and climate change. With the oil price at below $\$ 40$ per barrel, the biofuels industry is not currently a problem, but once the recession is over the issue of food versus fuel will reappear. Agriculture will need to adjust to more expensive fertiliser, fuel and transport, while pushing towards sustainability and lower environmental costs. It remains to be seen how energy efficient technologies can be developed with lower public R\&D growth and with many countries still avoiding any science that includes GM. 


\section{PROSPECTS FOR AGRICULTURAL PRODUCTIVITY GROWTH: WILL THERE BE A SLOWDOWN IN DEVELOPING COUNTRIES?}

\section{Jenifer Piesse, King's College London and University of Stellenbosch, RSA Colin Thirtle, Imperial College London and University of Pretoria, RSA}

\section{$1 \quad$ Introduction}

For much of 2008 soaring food commodities prices was a major news item. Rising prices are the market's signal that supply is not keeping pace with demand, so the events of 2008 have led to a reappraisal of the world's ability to feed itself. The prognosis was not good, especially when the data were more closely examined. The long standing conventional wisdom that science increases supply faster than population and income growth increase demand has to be questioned. It is possible that the long run prices stopped falling as much as 20 years ago, but few noticed. Thus, after persistent warnings that agricultural R\&D was no longer growing adequately and that there is a productivity slowdown, it is possible that now, after the long lags are worked through, productivity growth is falling. If so, either area expansion is needed, which is usually dismissed as the major source of growth, or yields need to rise. To investigate the prospects of agricultural productivity growth in the developing countries requires examination of the rich countries too and it cannot be confined to agriculture, but must consider how agriculture relates to the rest of the economy during the development process. Nor is agricultural economics a sufficient base, as it is the endogenous growth literature that explains the components of the process.

This paper begins by setting out the theory of how agricultural productivity growth occurs, all of which is evidence-based. This encompasses several elements including: the global links; the relationships between developed countries (DC) and less developed countries (LDC) R\&D; spillovers between jurisdictions; the common property aspects of both knowledge and technology; and the links between public and private $R \& D$ and between $R \& D$ and extension, farmer education and productivity growth. Further, productivity growth can be measured by yields, labour productivity or total factor productivity (TFP), all taking account of the temporal lags involved. This should be clearer following Professor Huffman's presentation.

Against this background, following a brief review of the theory related to productivity measurement in the next section, section three considers the evidence on prices and the explanations given in the literature for the long trend of falling prices. It culminates by outlining the stylised facts of a productivity slowdown. All the remaining sections try to address the "prospects", as in the title, by looking at recent events, in the changes and in the 
levels. Section four covers R\&D and productivity in the UK and the USA, since the rich countries provide the scientific and technological progress that powers the world system. Section five broadens the investigation to international comparisons and the LDCs. Section six reviews the scientific opportunities and constraints, including new technologies such as genetically modified crops. This lengthy analysis of the technological position is followed by a brief comment on the non-technical factors that affect productivity growth, including institutions, infrastructure, policy and governance. The section ends by summarising the main factors that are likely to cause major deviations over the next decade or more. These include the current financial crisis, biofuels, the oil price and climate change. The conclusion attempts to summarise and evaluate the evidence.

\section{Theory of International Productivity Growth: An Overview}

The two simplest productivity measures are partial: yield (which is just the average product of land) and the average product of labour. ${ }^{2}$ The literature on agricultural development, at least since Hayami and Ruttan's (1971) seminal contribution, stresses yield growth that results from the application of science and the mechanical revolution that followed Benz's invention of the internal combustion engine. Biological technology created improved fertiliser responsive plant varieties, which in combination with increased use of chemical inputs, caused yields to increase at historically unprecedented rates after the Second World War. The diffusion of hybrid varieties of crops such as maize, followed by the dwarf varieties of rice and maize and much improved disease resistance in many open pollinating crops like wheat, all contributed to continuing yield growth. This was further enhanced by improvements in modern chemical inputs. The Haber Bosch process for producing cheap artificial nitrogen goes hand in hand with George H Schull's discovery of hybrid vigour and so do the advances in the chemical industry that allowed a few drops of herbicide or insecticide to do what previously took gallons. These developments created the cheap modern land substitutes that induced the biological innovations that transformed yields, allowing the relative price of food to decline for decades, despite the relative fixity of land. Malthus could be forgotten, at least for a generation, as the biological/chemical revolution transformed $20^{\text {th }}$ century agriculture.

New data from Alston et al. (2008) shows that for the US, between 1866 and 2007 average yields of maize increased by a factor of six and wheat yields increased by a factor of 3.5. Over the past 100 years, rice and soybean yields grew by a factor of 3.9. For all four

\footnotetext{
${ }^{2}$ The alternative to partial measures is total factor productivity (TFP) which is total output per unit of all inputs, appropriately weighted.
} 
crops most of the yield gains occurred in the latter half of the $20^{\text {th }}$ century. Since 1950 annual average rates of growth for rice, wheat, and maize were typically 1-2\% greater than historical rates (1866-1949 for wheat and maize and 1919-1949 for rice).

Labour productivity increases began with animal power, but later reflect the other revolution of the $20^{\text {th }}$ century, which followed the invention of the internal combustion engine. The mechanical revolution has had even greater quantitative effects and has allowed the farm population in the most developed countries to shrink to below $2 \%$ of employment while producing far greater amounts of output indicated by the yield increases. Alston et al. (2008) report that in 2002, US agricultural production was more than five times its 1910 level. The increase in output from $1910-2002$ was $1.82 \%$ per year, achieved with only a $0.36 \%$ per year increase in aggregate inputs. Thus, from 1911 to 2002, yields increased by a factor of 4.4, labour productivity increased by a factor of 15.3 and TFP by a factor of 4.1 .

Similarly, by the early 1980s in the UK, the labour input required to produce crops like potatoes, sugar beet, wheat and barley was only one tenth the 1930 level and, over the same period, wheat yields increased by a factor of three (Grigg, 1989). From the Second World War to the early 1980s, tractor horsepower increased more than ten-fold and nitrogen fertilizer application grew by a factor of six (Holderness, 1985).

These achievements required massive and sustained expenditures on R\&D. The US expenditures are recorded by Huffman and Evenson (1992) and those for the UK by Thirtle et al. (1997). ${ }^{3}$ Much of the plant improvements were the work of the public sector, while mechanical innovations have been mostly attributable to private R\&D. The diffusion of both biological and mechanical innovations takes many years, so there is a long lag between the R\&D expenditures and the productivity gains at the farm level. For the UK, the lag seems to be about 27 years (Thirtle et al., 2008), for the US Pardey and Craig (1989) found lags of between 20 and 40 years and Huffman and Evenson (1992) calculated R\&D stocks using a trapezoid with a 35 year lag. R\&D produces yield gains at the trial plot level, which then requires expenditures on extension to take them to the farmer. ${ }^{4}$ Then, since more educated farmers are generally better at screening and adapting new technologies, farmer education also plays a role. There is also good evidence that spillovers between research jurisdictions are as important as direct benefits within countries (Schimmelpfennig and Thirtle, 1999). The relationship between public and private $R \& D$ has been less studied, but it seems likely that

\footnotetext{
${ }^{3}$ If there is any doubt that $\mathrm{R} \& \mathrm{D}$ does generate productivity growth, the review of the literature on the returns to R\&D by Alston et al. (2000) should be sufficient to convert even the most stubborn.

${ }^{4}$ Evenson (2001) reviews the returns to R\&D and also covers the importance of extension.
} 
the two are complements rather than substitutes (Thirtle et al., 2004). ${ }^{5}$ The relationship between basic and applied research was pioneered by Evenson, Waggoner and Ruttan (1979) and the lags between basic and applied research and diffusion are studied in Thirtle et al. (1998).

The international transmission of productivity enhancing technologies depends on the rate at which new technology becomes available, the extent to which it is allowed and encouraged to spill over into other jurisdictions and the capacity of the recipient countries to identify, customise and diffuse what is available. ${ }^{6}$ Hayami and Ruttan (1985) give an account of the development of sugarcane varieties that starts with Evenson and Kislev (1976) on the relationship between basic and applied science, through plant breeding and on into the international diffusion of genetic material and then research capacity.

The productivity gain will be limited by the weakest link in this chain, but basically from 1961 when data became available, the international system saw $R \& D$ growing at an increasing rate in both DCs and LDCs. This generated rapid productivity growth in the DCs and where there is substantial yield growth, it tends to mean that new varieties are being developed that can be fairly quickly adapted by the LDCs. There is technology "on the shelf" for the countries that follow the leaders and LDCs with good research capability can prosper under these circumstances. South Africa is a case in point. Following the establishment of majority rule there were over 4000 employees in the Agricultural Research Council and it even had biotechnology capabilities. Studies showed that the South African research system concentrated on adaptive R\&D and had consistently high rates of return (Thirtle et al., 1998, Townsend and Thirtle, 2001). But does the food price crisis indicate that productivity growth has slowed down?

\section{Food Prices and Implications for Productivity}

The suddenness and extent of the increases in world commodity prices in 2007-8 took the world by surprise, even the institutions that monitor the world food situation. However, the notion of soaring food prices is based on nominal prices. Wheat prices reached a peak in March 2008 and in nominal terms were 50\% higher than in the severe shortage of 1973 . If

\footnotetext{
${ }^{5}$ See Pray, Fuglie and Johnson for a recent review of the role and impact of private R\&D.

${ }^{6}$ The CGIAR focused on the production of international public goods (IPGs). That is, goods that are nonexclusive in access and non-rival in use, and that have widespread applicability. Thus, the role of spillovers is increasingly important (see Pingali and Kelley, 2007 and Maredia and Byerlee, 2000). Evenson and Gollin (2007) detail the complementary activities of the NARS.
} 
the nominal prices are deflated to constant 2007 \$US the 2008 peak is at less than $50 \%$ of the 1973 level.

Figure 1 shows the series in real terms, or constant \$US, which makes it clear that the current price spikes are more like the blips in the 1980s and 1990s than the 1970s crisis. None of these four commodities is anywhere near the 1974 peaks (1973 in the case of soybeans). As of April 2008, wheat was at 55\% of the 1974 peak, maize at 41\%, rice at $24 \%$ and soybeans at 39\%. This illustrates how powerful the downward trend has been. In real terms, food is still far cheaper than it was a generation ago.

Figure 1: Constant Prices for Bulk Commodities (1957-2008)

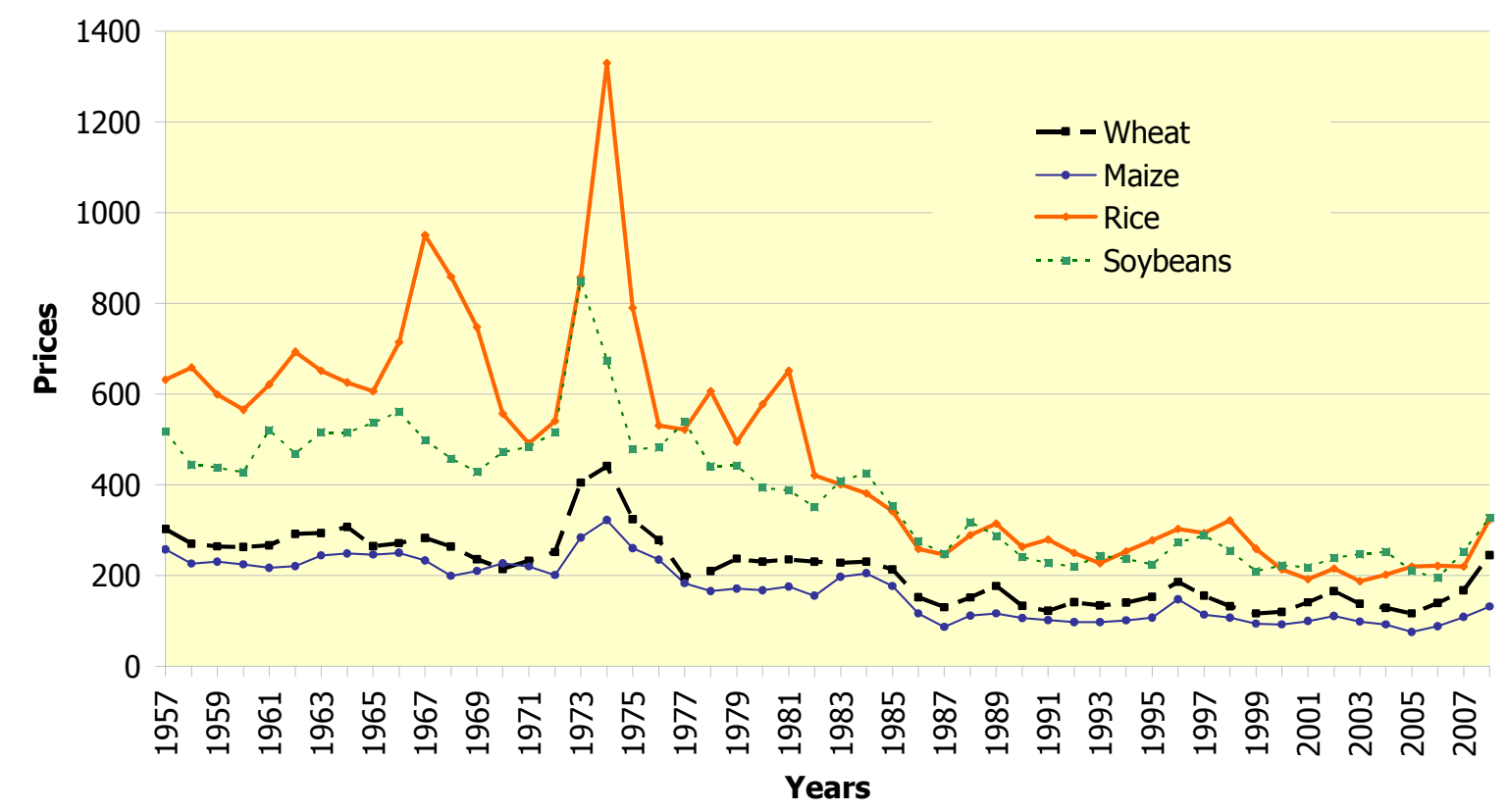

Source: FAO Internal data

However, these data do not show a steady decline in grain prices. Although the change was not noted by most observers before the 2008 price spike, FAO are now pointing out that the long term decline in grain prices was over long before $2006 .^{7}$ A more careful look at Figure 1 suggests that wheat and maize prices seem to be fluctuating around a fairly constant trend from the mid to late 1980s. Estimation of the growth rates confirms this. ${ }^{8}$ The first row of Table 1 confirms the visual impression, as although the growth rate of the wheat

\footnotetext{
${ }^{7}$ This position was clearly stated by Alexander Sarris at a conference at Wye College (Sarris, 2008). However, these conclusions follow from the FAO data used and other authors such as Alston et al. (2008) who use other sources are still saying that the long run trend is downward. No doubt the issue will be resolved eventually, but generally this report is hampered by disagreements based on different data.

${ }^{8}$ The growth rates are estimated by regressing the logarithm of TFP on a constant and a time trend. This is the method recommended by the FAO, for averaging the disparate changes over the period.
} 
price was negative, it is less than half a percent per annum and the $t$ statistic shows that this result is not significantly different from zero. Thus, it is fair to claim that wheat prices ceased declining as much as 20 years ago. Maize seems to follow wheat really closely and thus the result, in the next row, is similar, but not as strong. For 1987-2006 the growth rate is $-0.80 \%$ and the $t$ statistic is -1.56 , which again says that the trend is not significantly different from zero at the 5\% confidence level. In the next row, adding one more year, 2007, which is permissible in that the 2007 price was still lower than some previous years, makes this more emphatic. The maize growth rate falls to $-0.60 \%$ and the $t$ statistic to -1.16 , which is very similar to the result for wheat, as it is not significantly different from zero. Also, the maize price was below the 1987 level for only one year, 2005. These results do not constitute evidence of a declining trend.

Table 1: Trends in Main Grain Prices

\begin{tabular}{ccccc}
\hline Crop & Period & Growth Rate $\%$ & t statistic & Critical value $^{\mathrm{a}}$ \\
Wheat & $1987-2006$ & -0.48 & -0.96 & 1.73 (18 dof) \\
Maize & $1987-2006$ & -0.80 & -1.56 & 1.73 \\
Maize & $1987-2007$ & -0.60 & -1.16 & 1.73 \\
Soybeans & $1990-2004$ & +0.14 & +0.27 & $1.76(13 \mathrm{dof})$ \\
Rice & $1987-1998$ & +0.94 & +1.06 & $1.81(10 \mathrm{dof})$ \\
Soybean oil & $1987-2006$ & +0.60 & +0.38 & 1.73 \\
Rapeseed oil & $1987-2006$ & +1.69 & $+2.95^{* *}$ & 1.73 \\
Palm oil & $1987-2006$ & -0.04 & -0.05 & 1.73 \\
\hline
\end{tabular}

${ }^{a}$ Critical values are for a one tailed test at the 5\% confidence level. If the null hypothesis allowed for being significantly greater than zero, as well as less than (and the rapeseed result says it should) the critical value is 2.1 .

With no statistically significant fall in the prices of two of the four major grains for 20 years before the 2007/8 price spike it is odd that the conventional wisdom of falling agricultural prices was not challenged sooner. Correcting this oversight puts the causes of the $2007 / 8$ price spike in a new light. Why would the price decline have ceased by the late 1980s? The UK cuts in public agricultural R\&D began in 1982 and other developed countries followed suit. The cuts were accompanied by a re-direction of public funding, from productivity enhancing research to public interest issues, such as environmental protection, countryside stewardship, animal health and welfare and food safety. Both diminished the pool of open access technology available to the LDCs. The other DC's also reduced the funding available to the international system and the developing countries. However, the 
falling levels of investment in agriculture, caused by low profitability, was perhaps an even greater cause of decline.

Soybeans are different as the crop was growing in importance and the price decline starts only in 1990. There were low prices in 2005 and 2006, but if these years are excluded, the growth rate is positive but not significantly different from zero. Again, hardly evidence of an inexorable long run decline. Even for rice prices, which mostly appear to follow the conventional wisdom, the reality is that although rice prices were falling for the last decade, from 1987 there were a dozen years when the growth rate was almost plus 1\%, although again insignificantly different from zero according to the statistical tests.

These results are not confined to the four commodities shown above. Other prices are not pictured here, but can be found in the report on which this paper is based (Piesse and Thirtle, 2008). For vegetable oils, soybean oil stood in 2008 at $40 \%$ of its 1974 peak, rapeseed oil at $47 \%$ and palm oil at $41 \%$. Again, the conventional wisdom of falling prices can be quickly demolished. There is no sign of falling prices after 1987 and the last three rows of Table 1 confirm this. The trend for soybean oil and palm oil was not significantly different from zero. For rapeseed oil a decline is not only rejected but the positive growth rate of $1.7 \%$ is significant at the $1 \%$ confidence level. Thus, the only price that did not have a constant long term trend was rising rather than falling and actually rising quite fast. ${ }^{9}$

\subsection{Explaining the Long Run Trend in Prices}

The simplest analytical explanation of falling agricultural prices needs only Engel's Law (the relatively low income elasticity of demand for food) and the application of modern science to agricultural technology. This gives a generalised version of Cochrane's (1979) technology treadmill in Figure 2, which shows the dynamics of supply and demand. Driven by the technological innovations resulting from the application of science to agricultural technology, the supply curve shifts downwards and outwards each period due to the diffusion of technological change and increasing total factor productivity (TFP), while the demand shifts upwards due to population and income growth. For almost 50 years from WWII, supply increased faster than demand, which grows fairly slowly in accordance with Engel's Law, so that the locus of equilibrium points was falling over time. However, this may have been

\footnotetext{
${ }^{9}$ These FAO results are hard to reconcile with the statement in the 2008 WDR. "From 1980 to 2004, the gross domestic product (GDP) of agriculture expanded globally by an average of $2.0 \%$ a year, more than the population growth of $1.6 \%$ a year. This growth, driven by increasing productivity, pushed down the real price of grains in world markets by about $1.8 \%$ a year over the same period." (World Bank, 2008, page 50). This issue of the reliability of the data continues throughout this paper.
} 
changing. Income growth increases demand faster than population growth because switching to white meat relative from grains gives a multiple of three and switching to red meat and dairy gives a multiple of perhaps six. The biofuels market has also caused unprecedented additional demand growth.

\section{Figure 2: Long Run Decline in Food Prices}

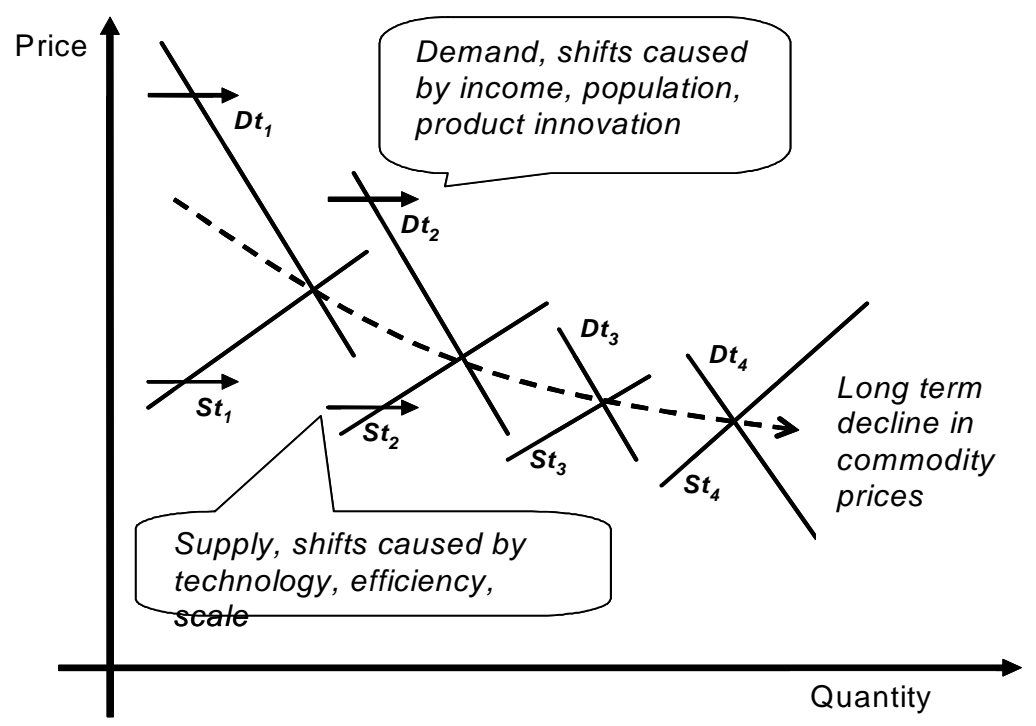

Source: David Hallam, FAO

The key point for this study is that almost all of the many authors of reports on the food price crisis (reviewed in Piesse and Thirtle, 2009) cite declining productivity as one of the causes of the price rises. However, Fuglie (2008) points out that the evidence does not really support this view, so it is investigated here.

\subsection{Increasing Output to Restrain Prices: Area Expansion or Yield Growth}

So, what can be expected of output growth? The two components of output are the area harvested and the yield per hectare. The 2008 WDR raises the importance of yield growth, pointing out that since 1961, area expansion has only been important in SSA. The IFPRI projections to 2050, shown in Figure 3, make it clear that even in SSA, the cultivated area is expected to grow at around $0.6 \%$ per annum, which is about one third of the contribution made by yield growth. In the Latin American countries, area expansion makes less than half as much of a contribution, for the rest of Africa it is effectively zero and for Asia, North America and Europe it is actually negative.

However, these estimates are confined to cereals. Latin America includes Brazil and Argentina, where there is extensive ongoing expansion of the soybean and sugar areas, which 
is swallowing up rough grazing on the pampas, small farms and forest. Surely this is a massive expansion of the cultivated area and a really major change?

Figure 3: Sources of Output Growth for Major Cereals

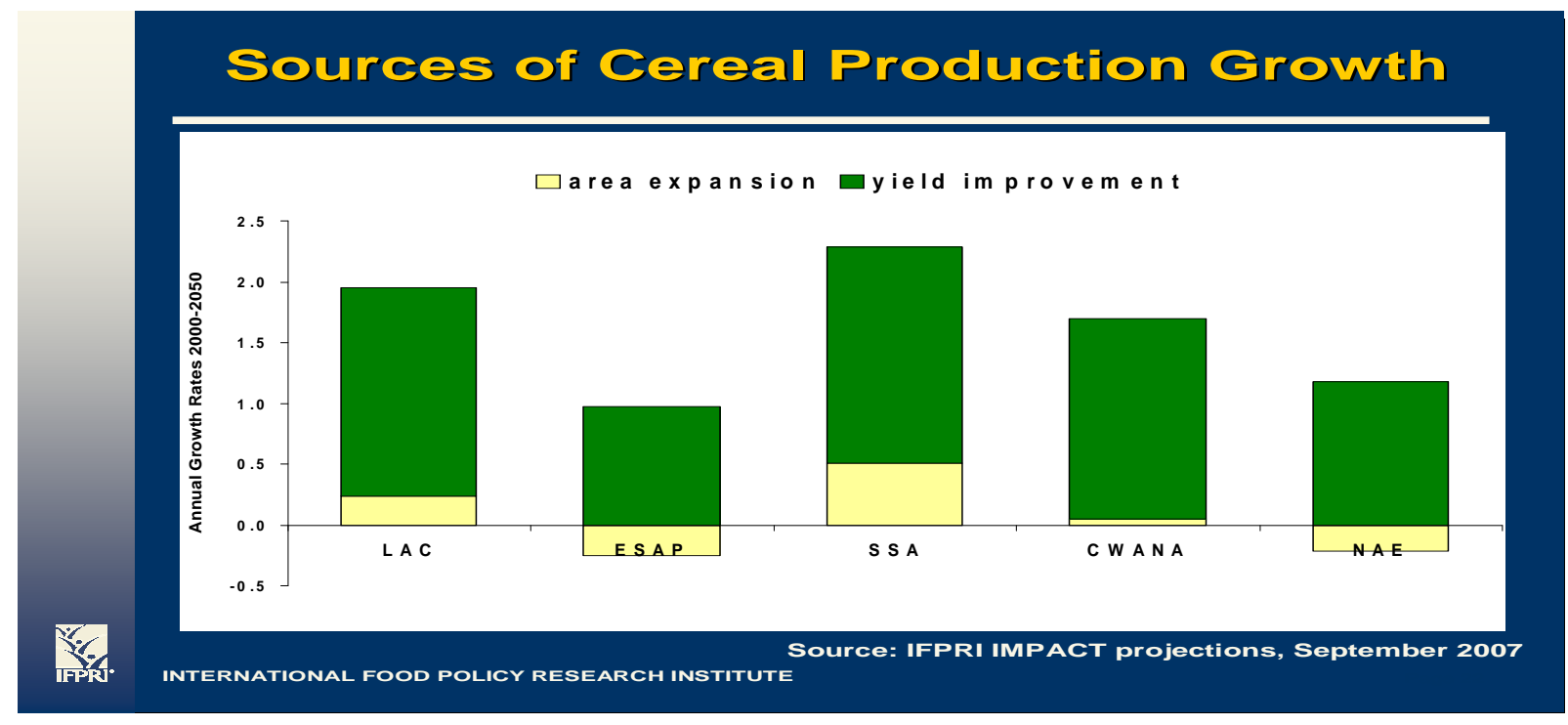

\subsection{A Menu for Productivity Decline}

Suppose that area expansion and changes in land use are limited options, then yield is the measure of productivity that matters if food security is the main concern. What would be the scenario that would lead to a demise in the growth that has powered the technology treadmill since World War II?

1) A decline in the growth of $R \& D$ expenditures in the DCs, leading to slower yield growth, hence less technology on the shelf and less scientific knowledge in the common property pool. This also results in less spillovers to the LDCs.

2) Financial retrenchment in the DCs leading to less aid for LDC agriculture and particularly less aid for LDC R\&D.

3) Less R\&D expenditure in the LDCs, combining with less external technology, to reduce yield growth in the LDCs. This is exacerbated by the fall in public R\&D and the rapid increase in private expenditures, as private companies are unable to make profits in poor countries.

4) The dominant green revolution technology is all but burnt out. All the easy gains have been made, so more effort is now required for less gain. 
This scenario is not implausible and some already subscribe to it, but is the evidence adequate to support such a case?

\section{$4 \quad$ R\&D and Productivity Growth in the Developed Countries}

Endogenous growth theory rests on the notion of positive spillovers that result from the nonrivalness of new technology, combined with the inability of firms to fully appropriate the returns to their research investments, lead to increasing returns at the aggregate level. Thus, technological spillovers form the basis of the increasing returns in Romer's (1986, 1990) models, just as they provide the rationale for public investment in agricultural research. Lucas (1988) introduces increasing returns in the aggregate production function by allowing individual human capital investments to have positive spillovers on the productivity resulting from the human capital investments of others. In both the Romer (1986) and Lucas (1988) models, policies that impede investment in human and physical capital reduce growth, and appropriate public policies accelerate growth.

The 1950s and 1960s saw science applied to agriculture in the DCs, with rapidly rising R\&D expenditures and productivity growth, whether measured by yields, labour productivity or TFP. The 1960s and 1970s saw this process extended to the LDCs, as the green revolution raised yields, especially in the densely populated countries of Asia. The DCs have good data that has been used to substantiate the claims made above. This is reviewed in this section as spillovers from the DCs should play a role in LDC productivity.

Figure 4: UK R\&D and Productivity

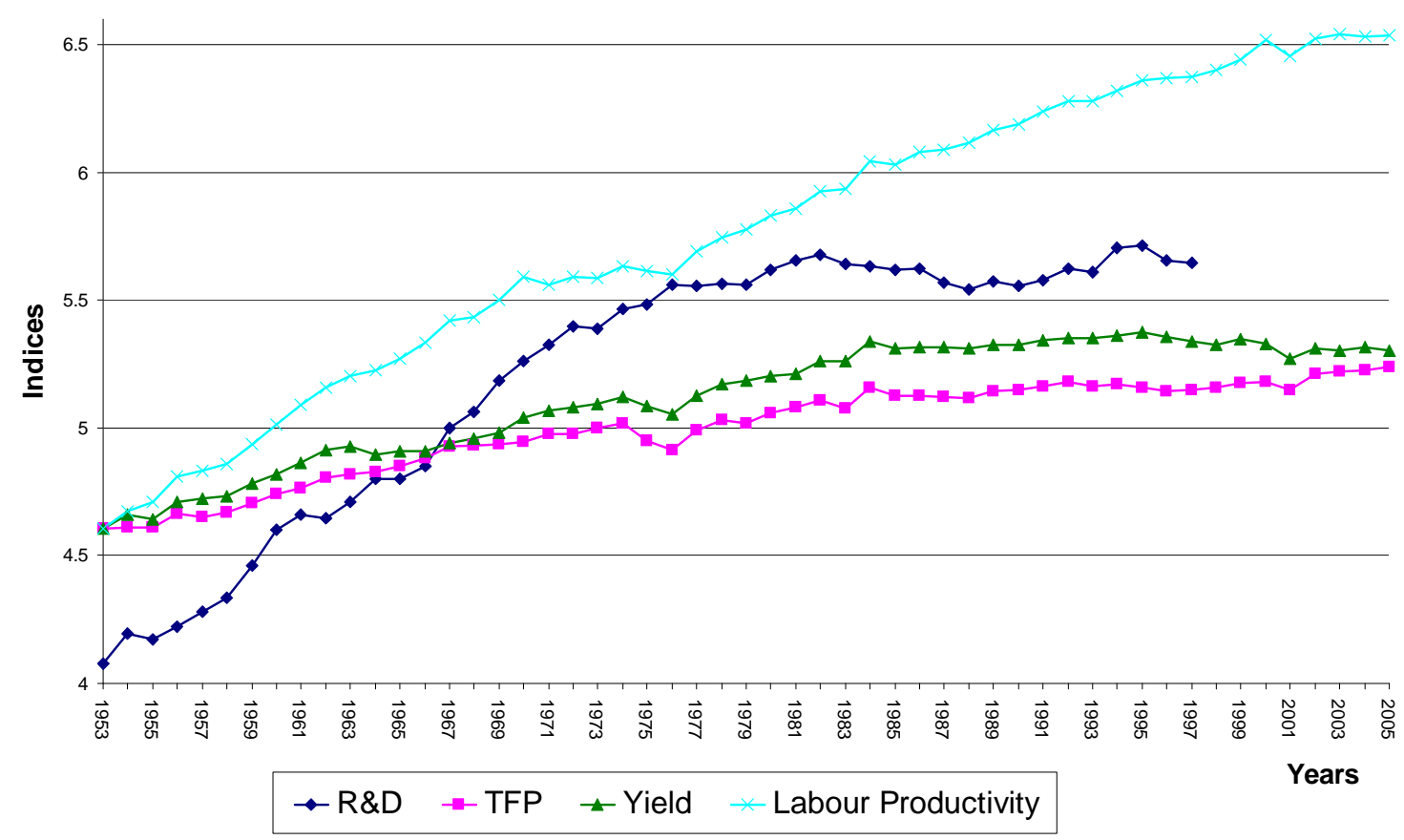


The UK took the lead in the changes that occurred in the 1980s. After growing at $6.6 \%$ per annum from 1947 to 1982 , Mrs Thatcher's cuts actually reduced UK agricultural R\&D expenditures at the rate of $1.7 \%$ per annum from 1982 to 1988. Figure 4 shows that there was then a mild recovery, but by 2000, expenditures were still lower than they had been in 1982 (Thirtle et al. 1997). By 1985 both yield and TFP practically ceased growing. Prior to 1984 TFP grew at $1.68 \%$ per annum and thereafter at only $0.26 \%$.

\section{Table 2: Annual Average R\&D and Productivity Growth Rates, for the UK, \%}

\begin{tabular}{rllccc}
\hline Years & & & \multicolumn{2}{c}{ Output per } & Output per \\
& $\begin{array}{c}\text { Output } \\
\text { Index }\end{array}$ & Input & TFP & Unit of & Unit of \\
$1953-2000$ & $1.40 \%$ & $0.14 \%$ & $1.26 \%$ & $1.64 \%$ & Land \\
$1953-1984$ & $1.89 \%$ & $0.20 \%$ & $1.68 \%$ & $2.11 \%$ & Labour \\
$1984-2000$ & $-0.12 \%$ & $-0.38 \%$ & $0.26 \%$ & $0.19 \%$ & $2.93 \%$ \\
\hline
\end{tabular}

Table 2 shows that output actually contracted and TFP only grew because inputs fell faster. Yield growth declined ever more, from $2.11 \%$ to $0.19 \%$, as Table 2 shows, so only labour productivity continued to grow rapidly. Finally, the UK data gives an indication that public $\mathrm{R} \& \mathrm{D}$ is not being replaced by private expenditures. Although the private sector now spends more than the public sector in the developed countries, Thirtle et al. (2004) found that when public expenditures fell, private sector activity, measured by UK patents, fell. Figure 5 shows that instead, foreign patents registered in the UK increased, so technology was imported rather than being produced domestically. This suggests that public R\&D still produces the scientific advances that private firm transform into patentable innovations. Thus, public and private research activities are complements rather than substitutes. 


\section{Figure 5: Public R\&D, UK and Foreign Patents}

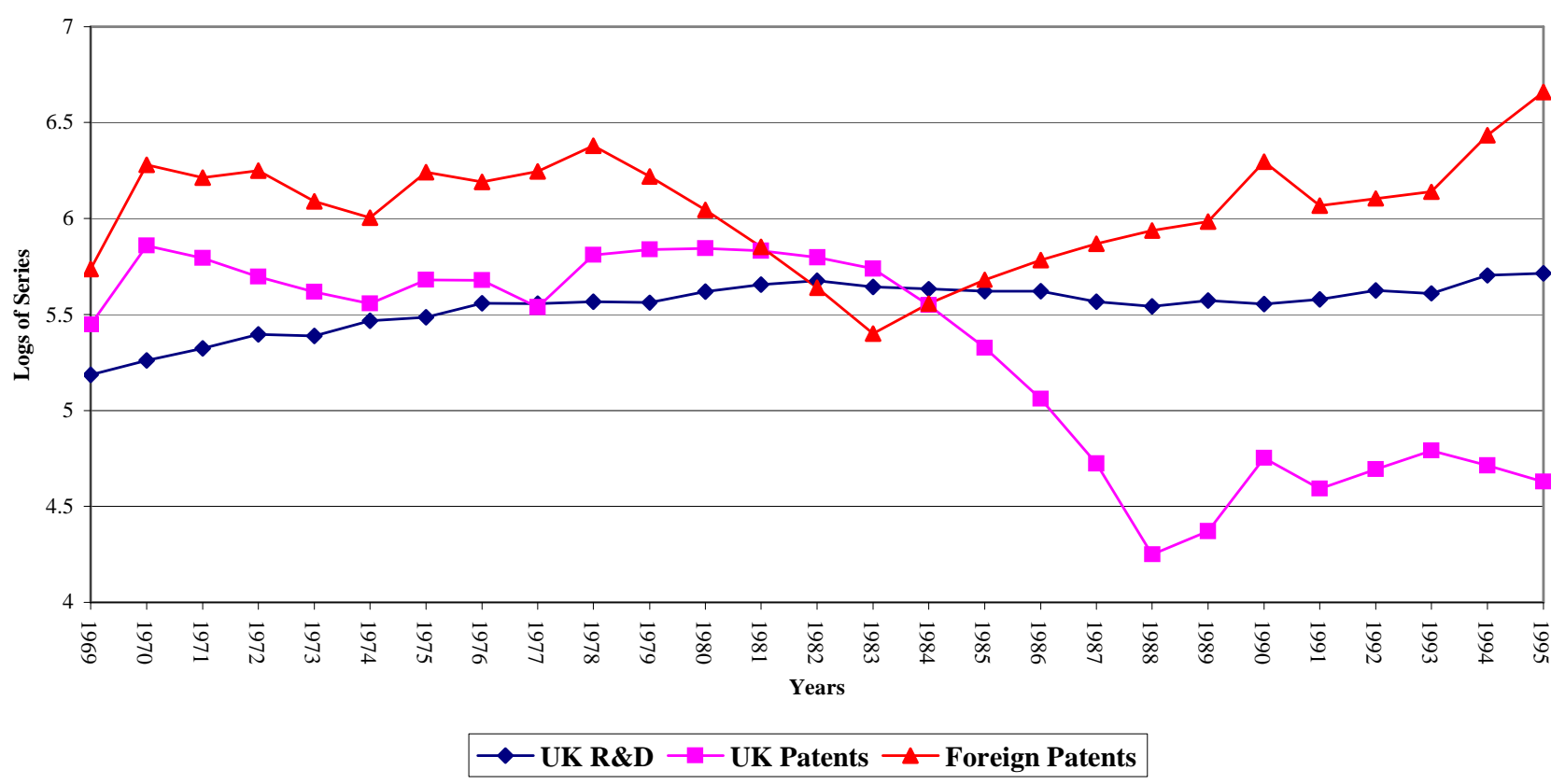

The agriculture sector in the UK is small and unimportant, but many of the DCs followed suit as political changes of the time led to privatisation and reduced public expenditures. Alston et al. (2008) show that the changes in the US system had similar, but less dramatic results, with $\mathrm{R} \& \mathrm{D}$, yields, labour productivity and TFP growth rates falling. Alston et al. (1999) show that for all the five countries studied (Australia, the Netherlands, New Zealand, the UK and the US) total R\&D expenditures fell in the 1980s, but recovered somewhat in the 1990s. However, the growth of expenditures was much slower than before 1980. Thus, they argue that there was a contraction in the growth of support for public agricultural R\&D amongst developed countries. While some countries increased expenditure in the latter half of the 1990s, albeit more slowly than in preceding decades, public agricultural R\&D was massively reduced in Japan, and to a lesser degree in several European countries, towards the end of the 1990s, leading to a reduction in the rate of increase in DC spending as a whole for the decade. More recent data, where available, reinforce the longerterm trends. Specifically, support for publicly performed agricultural R\&D amongst DCs is being scaled back, or is growing more slowly, and R\&D agendas have drifted away from productivity gains in food staples towards concerns for the environmental effects of agriculture, food safety and other aspects of food quality, and the medical, energy, and 
industrial uses of agricultural commodities. Given the role of international spillovers of agricultural technology, a continuation of the recent trends in funding, policy and markets is likely to have significant effects on the long-term productivity path for food staples in developed and developing countries alike.

However, the evidence of decline in the DCs is not entirely one sided. Figure 6 shows the UK agricultural TFP index keeping pace with that of France up to 1984 and then dropping out of contention with the leading EU countries. They do not seem to have suffered a decline in TFP growth, not even the Netherlands, which was cited as a country with falling R\&D growth in Alston et al. (1999).

\section{Figure 6: TFPs for the Leading EU Countries and the UK}

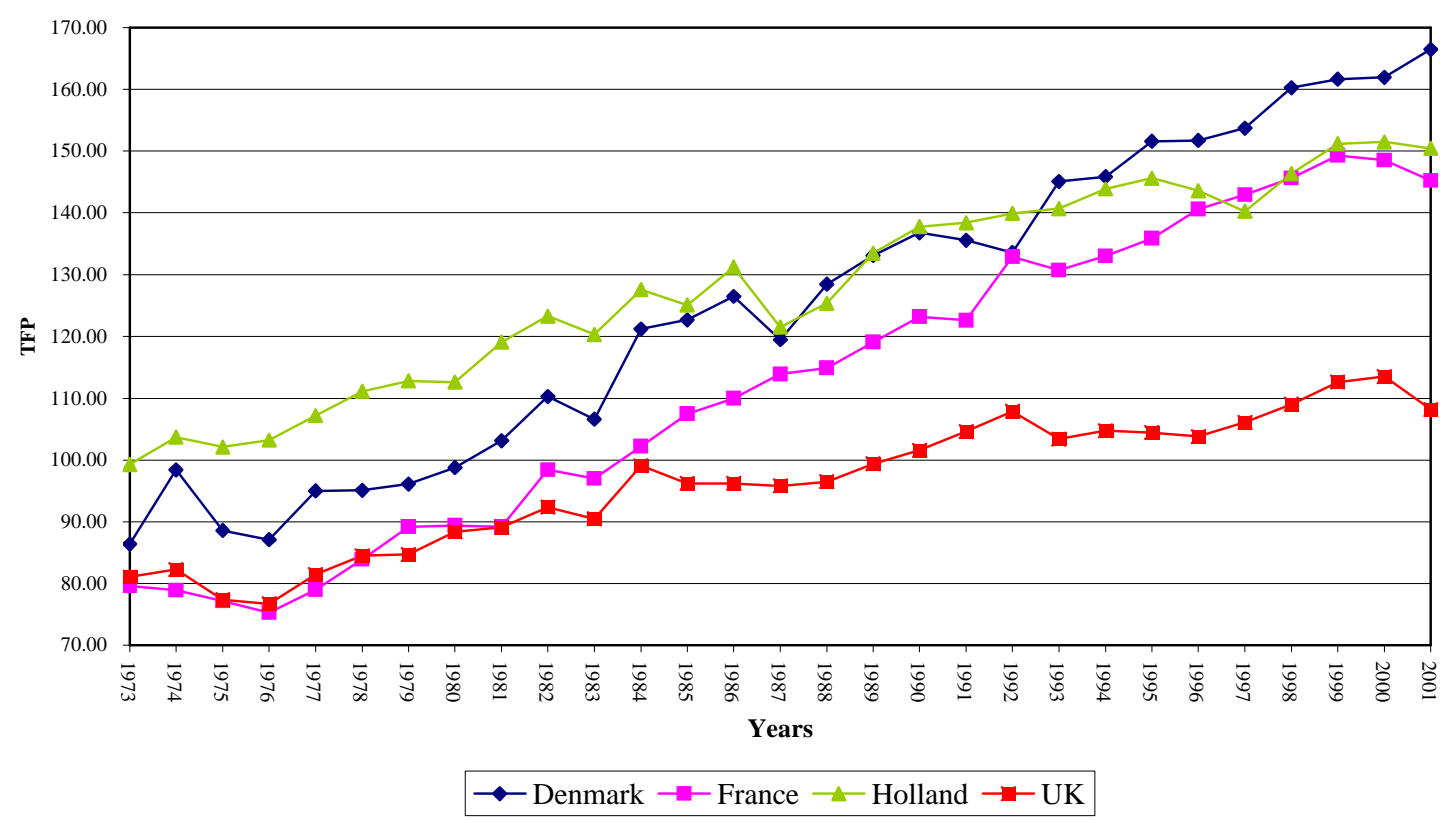

\section{$5 \quad$ International Comparisons of $R \& D$ and Productivity}

The data for the rest of the world are less detailed, but it is possible to assess the changes in R\&D and productivity for the LDCs.

\subsection{R\&D Expenditures in Rich and Poor Nations}

The longer term supply response depends on the availability of appropriate technology. Public R\&D expenditures for the high income countries fell from 10,534 million constant 2000 international US\$ in 1991 to10,191 million in 2000 (Pardey et al, 2006). This small fall is minor, but R\&D was also retargeted, away from productivity and towards public interest issues such as the environment, animal welfare and food safety. The allocation to 
productivity enhancing research declined substantially (Alston et al, 1999). The decline in the high income countries R\&D expenditures is shown in Figure 7, which summarises the world situation. The Figure shows that the rate of growth of agricultural R\&D expenditures has declined everywhere since the first period.

Figure 7: World R\&D Expenditures by Region and Income Level in 2000 \$

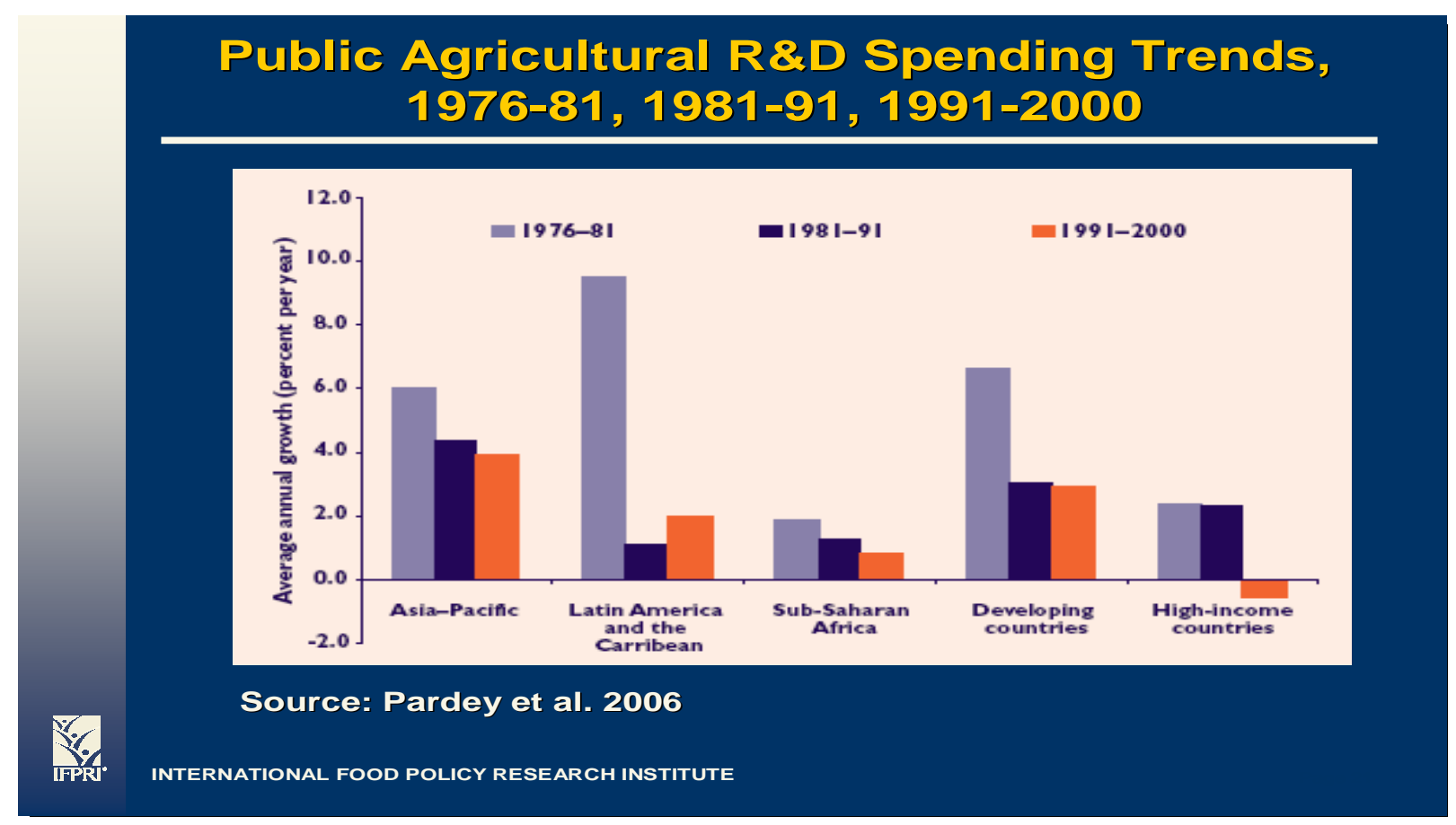

The data are expressed in constant 2000 \$ US, but there are now R\&D data in 2005 purchasing power parity (PPP) \$US. Beintema and Stads (2008) explain why PPP dollars are preferable, but the differences are not so great as to alter our arguments. ${ }^{10}$ Figure 8 summarises the new data, showing first that the SSA growth rate in the 1990s was negative. Agricultural R\&D spending in Sub-Saharan Africa decreased at an annual average rate of $0.2 \%$ during the 1990s and in about half of the 24 countries in the region, for which timeseries data were available. In addition, the public sector spent less on agricultural R\&D in 2000 than it had 10 years earlier (Beintema and Stads, 2006). For Asia and the Pacific, the decline is greater than in the old data, as the 1970s growth rate has been adjusted upwards to 8\%, whereas for Latin America and the Caribbean, the decline of the 1980s is less sharp. The biggest change is that the decline for the developing countries is greater than in the old data, while that for the high income countries is less severe, with the growth rate now low but still

\footnotetext{
${ }^{10}$ The Agricultural Science and Technology Indicators (ASTI) website has updates of world agricultural R\&D figures, which have also changed because the World Bank has issued new deflators.
} 
positive in the 1990s. These regional trends hide a growing divide between the scientific haves and have-nots. In the Asia-Pacific region, just two countries, China and India, accounted for $89 \%$ of the $\$ 42.5$ billion increase in regional spending from 1995 to 2000 . Thus, China and India accounted for 59\% of the region's scientific spending in 1995, jumping to $73 \%$ of the regional total by 2000 .

Figure 8: World R\&D Expenditures by Region and Income Level in PPP \$ US

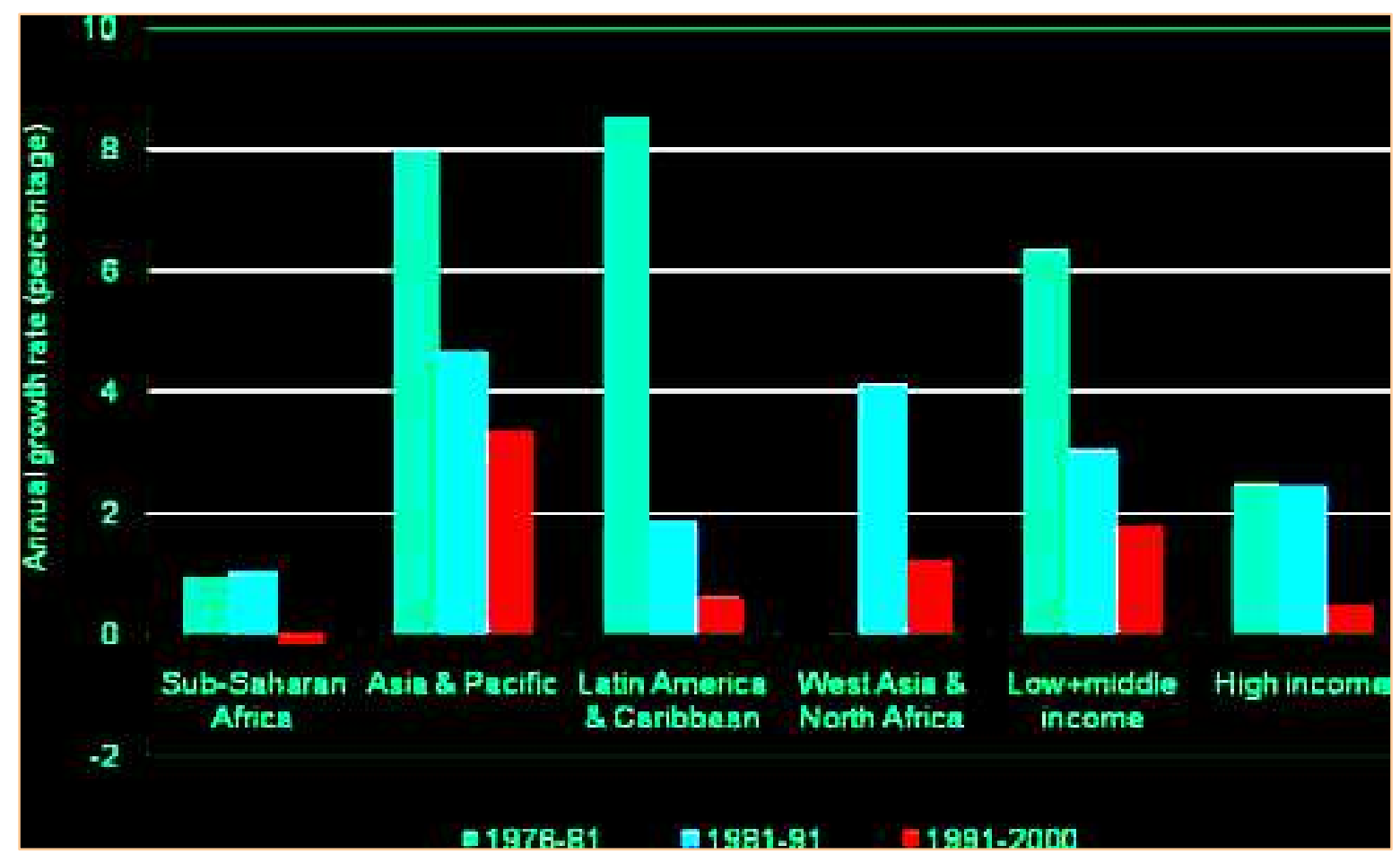

Source: Beintema and Stads (2008)

Ideally, this investigation would be able to track the effects of declining $R \& D$ growth rates to lower rates of productivity growth in the DCs and the transmission of the decline to the LDCs. Unfortunately, this has not been achieved in the literature to date and may well be impossible, as there are too many other interacting factors affecting productivity. Thus, SSA should have gained from the high rates of technology generation early in the period and by now be suffering from the downturn in both the DCs and the abysmally low SSA expenditures. Instead, SSA has always lagged so far behind that it is only now showing signs of better growth. This is the result of better policies, institutions and infrastructure, and more 
robust systems of governance, all of which are allowing the backlog of available technology to finally be exploited to an extent. ${ }^{11}$

One issue on which our understanding is extremely poor may be the basic explanation of why $R \& D$ growth is needed to sustain productivity growth. It is well understood that some percentage of expenditures is necessary to maintain current productivity levels. Blakeslee (1987) invoked the help of the Red Queen to explain the importance of maintenance research:

“A slow sort of a country!” said the Queen. “Now, here you see, it takes all the running you can do, to keep in the same place. If you want to get somewhere else, you must run at least twice as fast as that!”

Lewis Carroll (1872)

Blakeslee estimated econometrically that as much as $90 \%$ of R\&D may not be productivity enhancing, but necessary to prevent productivity losses. A more widely accepted estimate from Adusei and Norton (1990), based on a survey of US agricultural researchers, reported that they classified about one third of their efforts as maintenance research. Townsend and Thirtle (2001) showed that for animal production in South Africa, there was a rate of return of at least $35 \%$ for animal health research (maintenance) and $27 \%$ for productivity improvements research.

\subsection{Output and Yields}

The World Development Report (WDR) (World Bank, 2008) reports that developing countries achieved much faster agricultural growth $(2.6 \%$ a year) than industrial countries (0.9\% a year) from 1980 to 2004, accounting for $79 \%$ of growth. Their share of world agricultural GDP rose from $56 \%$ in 1980 to $65 \%$ in 2004, with the transforming economies in Asia accounted for two-thirds of the developing world's agricultural growth. The major contributor to growth in Asia, and the developing world in general, was productivity gains rather than expansion of land devoted to agriculture. Cereal yields in East Asia rose by an impressive $2.8 \%$ a year in 1961-2004, much more than the $1.8 \%$ growth in industrial countries. Only in SSA did area expansion have more impact than growth in yields. ${ }^{12}$

\footnotetext{
${ }^{11}$ Not that all agree that SSA has always fared as poorly as much of the literature suggests. For example, Thirtle et al.(1995) reported positive TFP growth in 17 of 22 countries in SSA using index number techniques and Wiggins (1995) was equally positive on the basis of reviewing the literature.

12 The WDR adds that "Due to rising productivity, prices have been declining for cereals-especially for rice, the developing world's major food staple — and for traditional developing-world export products, such as cotton and coffee." Not good for a publication that appeared as food prices hit crisis levels.
} 
The FAO (2005) and USDA (2009) both report yields for individual crops, measured in physical terms. The World Bank (2007) data is in terms of agricultural value added per hectare, in constant 2000 \$ US, which obviously allows for enterprise switching and includes all outputs, such as animals and animal products. Both are reported here, beginning with the physical yield results in the WDR (World Bank, 2008). There was an expectation of yield growth, but Figure 9 shows that for the most important cereal crops the growth rates in the developing countries were $3 \%$ or better at the height of the green revolution in the early 1980s. Since then the growth rates have fallen so that by 2000 , the rates for rice and wheat were about $1 \%$ and maize a little better at around $1.5 \%$. There seems to be a slight recovery since 2000 , which is surely needed as these growth rates are less than population growth and per capita food availability would be falling.

\section{Figure 9: Developing Country Productivity Growth Rates for Major Cereals}

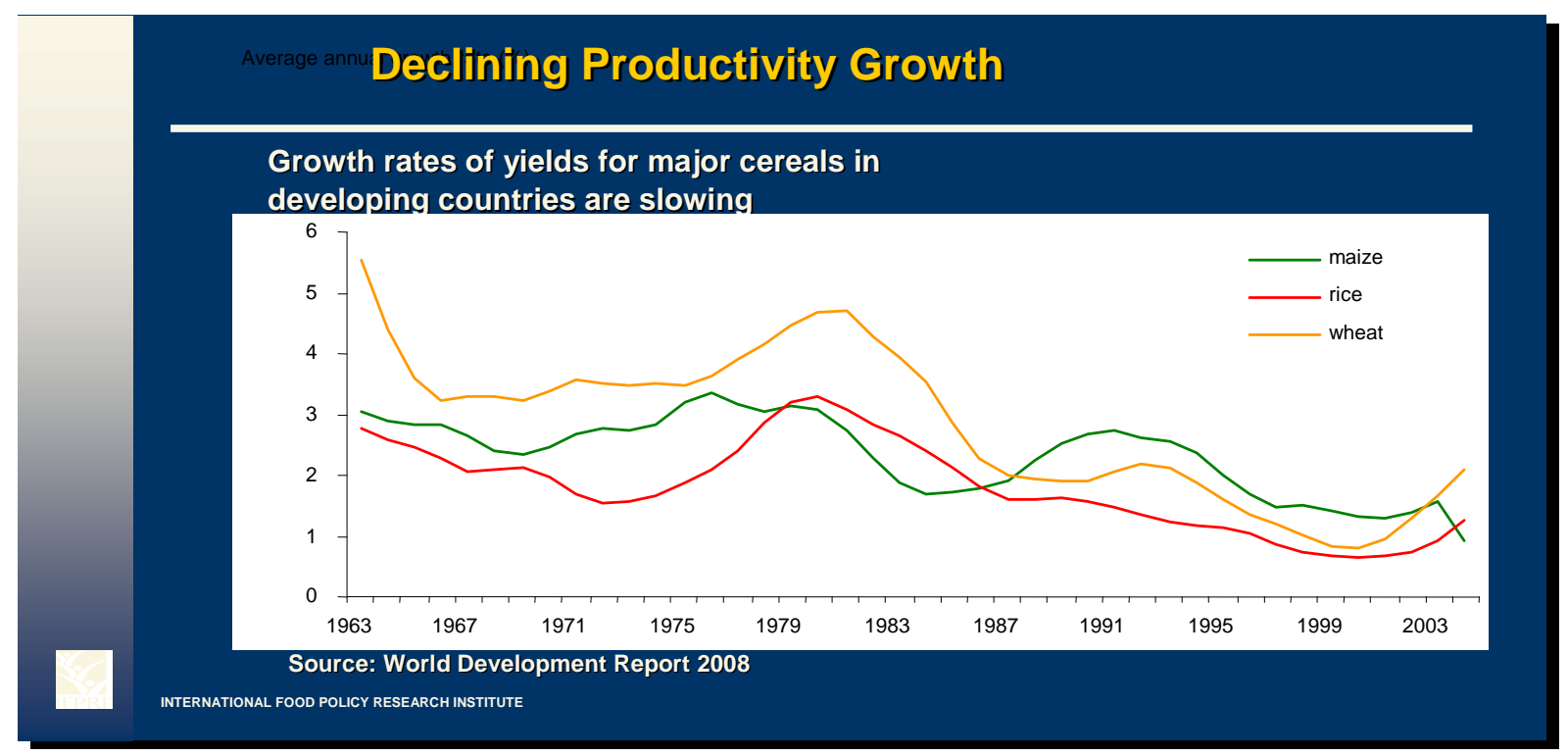

The 2008 World Development Report (WDR)

The WDR results seem somewhat extreme and may be a case of careful selection to support a point, rather than scientific objectivity. Indeed, calculations based on the available yield data show that not all LDCs are suffering declining yields. Our calculations are split pre and post 1985 as that did seem to be the year at which there is a downturn, see Table 3. Even so, our results show that all of Africa is doing substantially better and South American almost doubling yields in the second period. These positive results need to be set against decline in the other six regions, which reduces LDC yield growth overall from $2.5 \%$ to $1.6 \%$. However, this performance is good relative to the DCs, 
where growth rates have crashed to one third of their pre 1986 levels. Thus, the greater decline in the DC's R\&D growth is possibly a cause of the greater decline in yield growth, but other factors need to be considered too. The gains from hybrids and the green revolution-type technologies were exploited earlier in the DCs, so by the second period progress may be more difficult. Note too, that North America, which is exploiting the major new technology, genetically modified (GM) crops, has no significant fall in yields, whereas the other DCs who so far are reluctant to embrace this science, are doing extremely poorly.

Table 3: Yield Growth Rates - All grains

\section{Regions} 1961-2008 $1961-1985$ 1986 - 2008

Developed Countries

$\begin{array}{lccc}\text { North America } & 1.834 & 2.08 & 2.00 \\ \text { Oceania } & 0.969 & 0.65 & -0.059^{*} \\ \text { European Union } & 1.779 & 2.86 & 0.80 \\ \text { Former Soviet Republics } & 1.237 & 1.78 & 0.518^{*} \\ \text { Europe (non-EU) } & 1.485 & 3.45 & 0.326^{*} \\ \text { DC Average } & \mathbf{1 . 4 6} & \mathbf{2 . 1 6} & \mathbf{0 . 7 2} \\ \text { LDCs } & & & \\ \text { North Africa } & 2.079 & 1.45 & 2.10 \\ \text { Sub-Saharan Africa } & 0.017^{*} & 0.47 & 0.96 \\ \text { South America } & 2.218 & 1.63 & 3.15 \\ \text { Caribbean } & 1.43 & 2.51 & 0.62 \\ \text { Central America } & 1.46 & 2.16 & 0.40 \\ \text { East Asia } & 2.86 & 3.90 & 1.49 \\ \text { Middle East } & 1.914 & 2.13 & 1.83 \\ \text { South Asia } & 2.353 & 2.24 & 2.15 \\ \text { South East Asia } & 1.912 & 2.08 & 1.43 \\ \text { LDC Average } & \mathbf{2 . 1 0} & \mathbf{2 . 5 0} & \mathbf{1 . 5 7}\end{array}$

Source: Calculated from USDA (2009). Note: these growth rates were measured by regressing the natural logarithm of yield on time. The values marked *indicate growth is not significantly different from zero

As a general proposition, the low yield grow in the DCs must mean that there is less technology available to the LDCs later, so the falling yields in Asia may reflect this development. It would fit too, that Africa has not yet reached this point in the sequence of diffusion. The work on spillovers by Quah (1997) and others suggests clear patterns and within agricultural economics information is quite limited, but Schimmelpfennig and Thirtle (1999) found that there was a cascade effect for the US and the EU countries. The spillovers were from the US to Northern Europe, from there to Italy and from Italy to the least technologically advanced countries like Greece. This would suggest that the lags could be 
very long. SSA may be able to continue finding technologies for a long time before catching up with Asia, as Asia slows due to less spillovers from the US and Europe.

\subsection{Labour and Land Productivity}

Labour productivity is the other partial measure that is commonly reported and it is of interest not because of the world food security situation, but because wages, incomes and economic welfare are dependent on how productive the labour force is. It is well established that in keeping with the induced innovation hypothesis, productivity change in the DCs has a strong labour saving bias, whereas the land scarce countries of Asia had relatively land saving technological change. Africa, where a substantial number of countries have practically unlimited supplies of marginal land, has always failed to fit the induced innovation hypothesis at all well (Ruttan and Thirtle, 1989).

The yields above are measured in physical terms, but the World Development Indicators data (World Bank, 2007) are published with yields measured in value added per hectare, at constant 2000 \$US. This incorporates all outputs and allows for crop switching, so it may give lower or higher yields than the FAO crop level data. It has also been used to estimate labour productivity for Africa and Asia (Thirtle and Piesse, 2008). The averages for both land and labour productivity were estimated by regressing the productivity measure on time using a random coefficients model to give an average for the region.

The regional averages are reported in Table 4, starting with the yield for all three groups of developing countries, by continent, which is much the same sample as all the LDCs in Table 3. This average yield is lower at $1.7 \%$ in the first period, but instead of falling, it rises slightly in the second period. Either enterprises other than basic cereals have done better, or switching to higher valued enterprises has contributed to the increase in output value, or both. The Asian average for 1961-2006 of 2.6\% is well above the average for Africa, which is $2.0 \%$, but this is far higher than most would expect, given that African agriculture is regarded as failing. Over half the African sample (22 of the 42 countries) had yield growth of over $2 \%$ and only eight had less than 1\%. Latin America and the Caribbean countries have lower yield growth, but again no decline. Thirtle and Piesse (2008) did not cover the DCs, but the last row in this section shows that former Soviet Union (FSU) and nonEuropean Union countries of Europe actually had poorer yields than the developing countries. 
Table 4: Growth in Yields and labour Productivity Using Value Added Data (\%)

\begin{tabular}{lccc}
\hline Region & $\mathbf{1 9 6 1 - 2 0 0 3}$ & $\begin{array}{c}\mathbf{1 9 6 1 - 8 5} \\
\text { Yields }\end{array}$ & $\mathbf{1 9 8 5 - 2 0 0 3}$ \\
Africa, Asia, Latin America \& Caribbean & 1.79 & 1.70 & 1.79 \\
Africa and Asia & 2.14 & 1.55 & 2.27 \\
Africa & 2.00 & 1.37 & 2.11 \\
Asia & 2.60 & 2.14 & 2.75 \\
Latin America and Caribbean & 1.22 & 1.27 & 1.36 \\
FSU and Europe Non EU & 0.54 & 1.94 & 0.55 \\
& & Labour Productivity \\
Africa & 0.40 & 0.015 & 0.80 \\
Asia & 1.50 & 1.34 & 1.56 \\
Latin America and Caribbean & 1.35 & 1.51 & 1.48 \\
Europe - Non EU Countries & 3.36 & 3.00 & 3.40 \\
EU Countries & 4.13 & 4.93 & 3.41 \\
\hline
\end{tabular}

The lower part of Table 4 shows that yield growth in Asia translated into labour productivity growing at an average of $1.5 \%$, with only five of the twelve countries had less than $1 \%$ growth. For Africa, labour productivity grew at only $0.4 \%$ per annum and although the top few countries are in the same league as Asia, almost half the sample (18 countries) actually have negative growth of labour productivity. There is a clear contrast between the poorest countries and both Europe groups, EU and non-EU, which have much rather more than twice as much labour productivity growth. This follows from the induced innovation hypothesis, as labour is the scarce resource in the DCs. It also fits the view that labour productivity is closely linked to incomes, as the European countries, especially the EU member states, are substantially better off.

The poorest countries on earth are all predominantly agricultural, whilst the richest have now moved beyond being purely industrial but rather their economies are dominated by the service sector. The greatest empirical regularity in economics is the structural transformation, whereby during the development process agriculture declines in importance relative to first industry and later services. This is sufficient reason for not looking at agriculture alone, but in conjunction with industrialisation and urbanisation, particularly as these forces in their turn critically affect levels of pollution and the consumption of scare natural resources, such as water. This level of circularity complicates attempts at explain the trends in productivity and makes causality difficult to determine, as it may not operate in one direction only. The underlying cause of the relative decline of agriculture in the structural transformation is that the income elasticity of demand for agricultural goods is lower than that for manufactures and services. 
Labour productivity does matter and it tends not to increase dramatically until a country has passed the turning point in the structural transformation, at which the total numbers employed in agriculture starts to fall. Thus, it is labour demand by industry and manufacturing that is needed to give agricultural labour other options. There is a substantial literature on the structural transformation, which is seriously in need of updating. ${ }^{13}$

From the beginning of the transformation, agricultural output and employment decline relatively, but since industrialisation has been accompanied by population growth, it is only when the industrial sector has become large enough to absorb more than the increase in numbers that agriculture begins to decline in absolute terms. This is the "turning point" and Table 5 shows the date of the turning point and the percentage of labour in agriculture at that date for 29 countries. The ordering in the Table is determined by the percentage labour in agriculture when the turning point was reached. Apart from South Africa, which is a special case, because it is a dual economy highly dependent on mining, the other six countries that head the list were all dominated by the USSR at the date of their transformation.

Table 5: Date at which the Agricultural Labour Force Begins Decline and \% in Agriculture

\begin{tabular}{|c|c|c|c|c|c|c|c|c|}
\hline Country & Date & $\%$ & Country & Date & $\%$ & Country & Date & $\%$ \\
\hline USSR & 1926 & 86.1 & Japan & 1947 & 52.6 & Austria & 1939 & 39.0 \\
\hline Romania & 1930 & 78.7 & Spain & 1950 & 48.8 & Germany & 1907 & 36.8 \\
\hline Yugoslavia & 1948 & 77.8 & Portugal & 1950 & 48.4 & Denmark & 1930 & 35.6 \\
\hline Bulgaria & 1946 & 75.3 & Italy & 1936 & 48.2 & Norway & 1931 & 35.3 \\
\hline South Africa ${ }^{*}$ & 1921 & 69.5 & Luxembourg & 1967 & 44.5 & USA & 1910 & 31.6 \\
\hline Finland & 1940 & 57.4 & Belgium & 1866 & 44.4 & Canada & 1941 & 27.2 \\
\hline Poland & 1950 & 57.2 & Switzerland & 1880 & 42.4 & New Zealand & 1936 & 27.2 \\
\hline Hungary & 1949 & 52.9 & France & 1921 & 41.5 & Argentina & 1947 & 25.2 \\
\hline \multirow{3}{*}{$\begin{array}{l}\text { Average East } \\
\text { Europe }\end{array}$} & & 69.3 & Sweden & 1920 & 40.2 & Great Britain & 1851 & 21.9 \\
\hline & & & Czechoslovakia & 1921 & 40.3 & Australia & 1933 & 20.5 \\
\hline & & & & & & Netherlands & 1947 & 19.3 \\
\hline
\end{tabular}

Source: Grigg (1982), Table 11, page 109. " South Africa is not included in the Eastern Europe average.

The main interest here is that when countries pass the turning point, their economies change dramatically. Labour productivity in agriculture has to increase rapidly enough for the

\footnotetext{
${ }^{13}$ For a brief review see Piesse and Thirtle (1997)
} 
falling rural and agricultural population to feed the growing urban, industrial labour force. Little work has been done in this area for some time, but China passed the turning point some years back, as Figure 10 shows. Despite policies to prevent rural-urban migration that delayed the turning point, the agricultural population has been declining since 1999. The data for India is not available past 1995 , but it seems probable that India too has reached the turning point. ${ }^{14}$

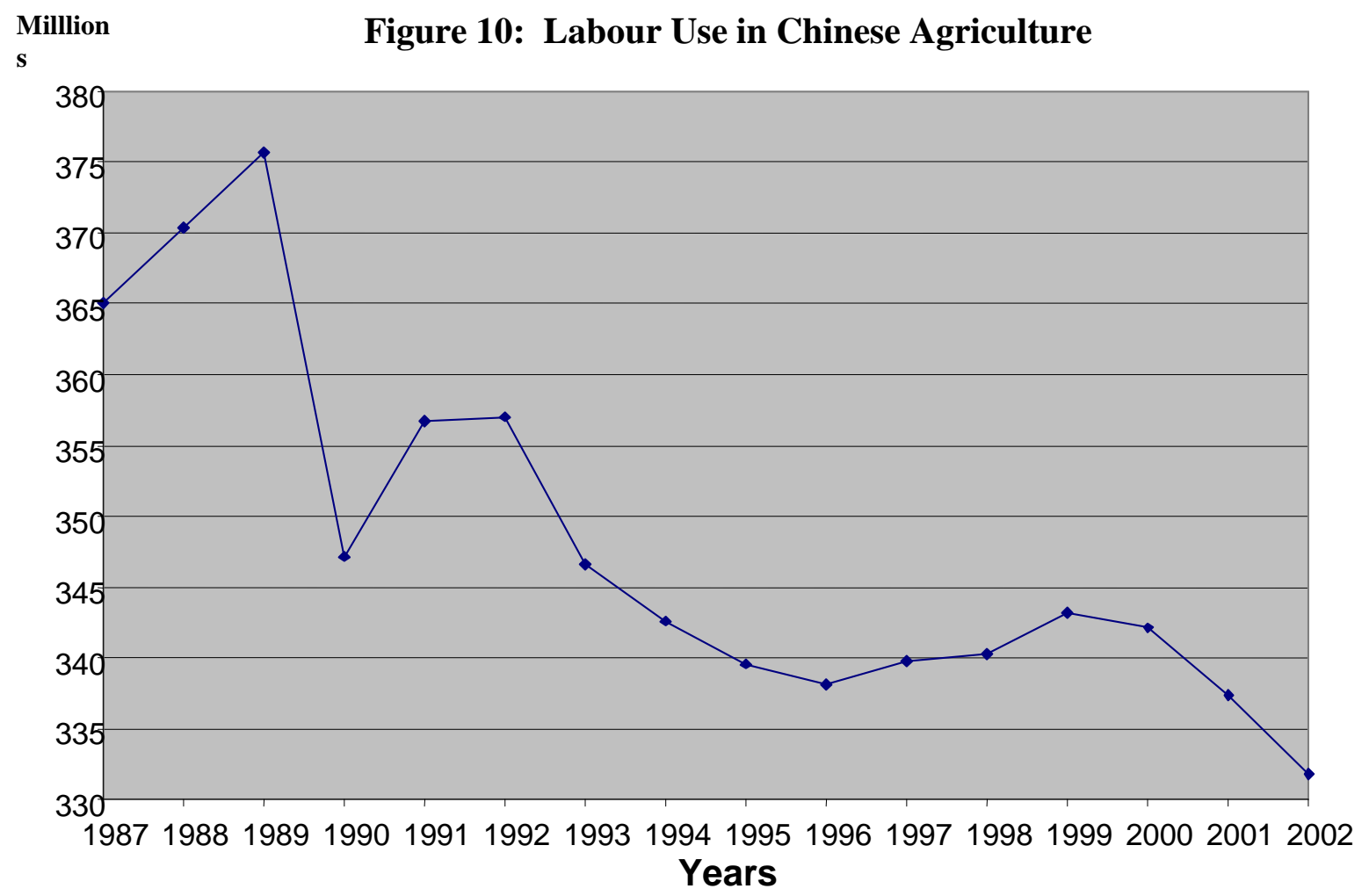

Source: World Bank: World Development Indicators, 2007

The World Bank data on the concomitant growth of industry and urbanisation is too incomplete to help here, but energy consumption is shown in the next Figure. The steady increase in energy use for both countries is clear, but from 2001, China's rate increases dramatically as the economy entered this transformation stage.

\footnotetext{
${ }^{14}$ China and India are picked out as they account for over $40 \%$ of world population, but others that have passed the turning point are Brazil, Colombia, Egypt, Korea, Malaysia, Mexico, Nicaragua, Saudi Arabia and Tunisia.
} 


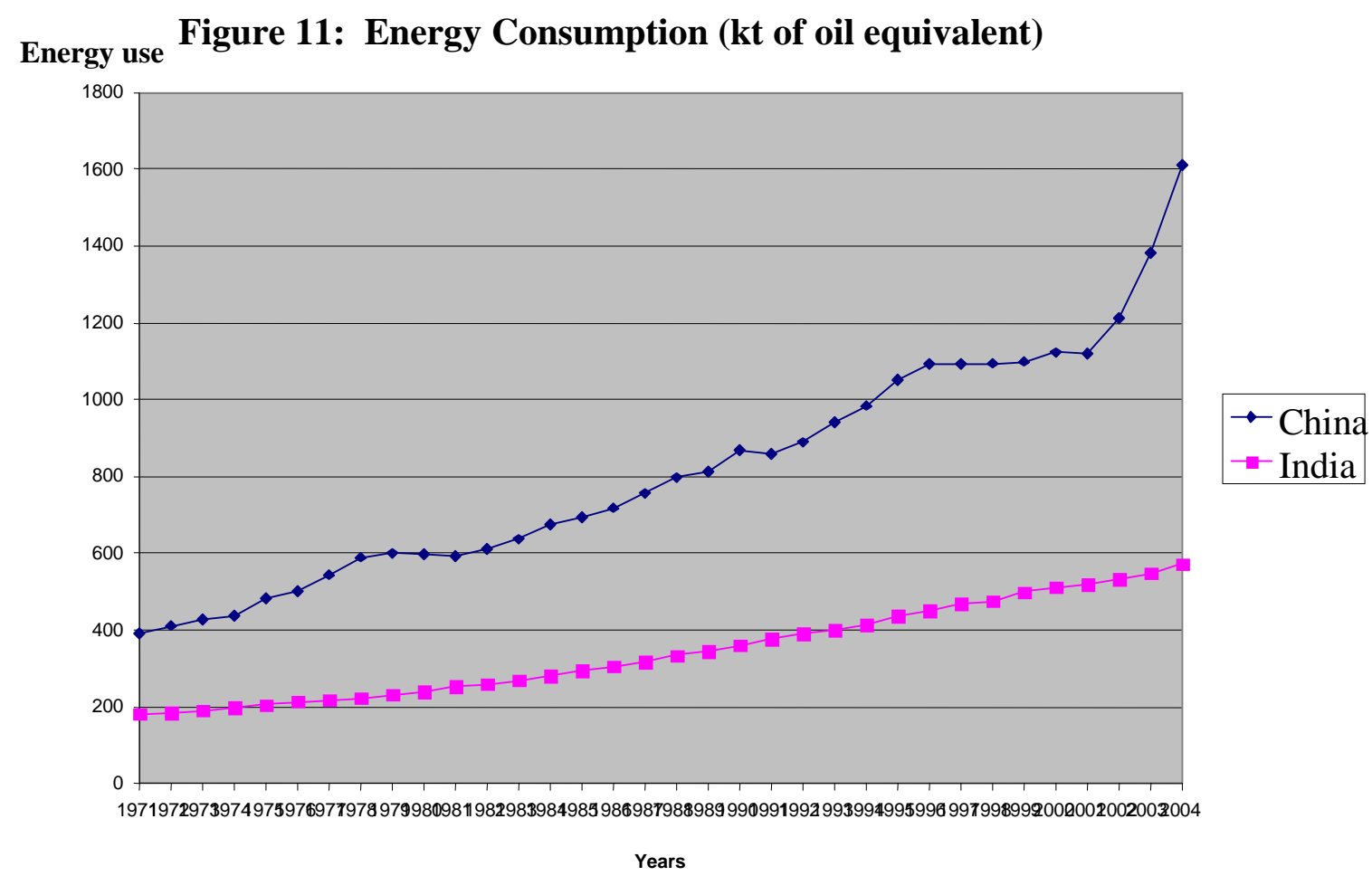

Source: World Bank: World Development Indicators, 2007.

Once the turning point is passed, agricultural outputs continue to increase, but using less labour. This requires first animal and then mechanical power and the mechanical revolution was a dominant feature of developed country agriculture in the $20^{\text {th }}$ century. The other was the fertiliser revolution, or more broadly the chemical revolution, whereby yield increasing chemicals were substituted for land, thus increasing yields. The two processes together have a massive effect on the size of the agricultural sector. Table 7 showed that at the turning point agriculture accounted for 20 to $50 \%$ of employment in the non-USSR countries and a rather lower share of GDP. These shares are now below $2 \%$ in most of the advanced countries, where the majority of the value of agricultural products can be attributed to manufactured inputs that are imported into the agricultural sector. To use the UK as an example, by 2005 the employment share of agriculture was down to $1.8 \%$ and the share of total output measured by gross value added had been reduced to 0.5\% (DEFRA, 2006a).

These huge changes have serious implications for the rate and direction of technical change in agriculture. Biological technical change may continue, but it is quite quickly outweighed by mechanical technical change. Figure 12 shows the change in the ratio of yield growth to labour productivity growth for Brazil and as soon as the agricultural labour force starts to decline, labour productivity dominates. And Brazil is not atypical. In China and 
India, labour productivity in agriculture must be expected to grow industry and services absorb more labour and urbanisation increases the size of the market. The path of labour productivity for countries that are passing this transitional point is pretty clear, but yields are more uncertain.

Figure 12: Productivity Bias and Turning Point for Brazil

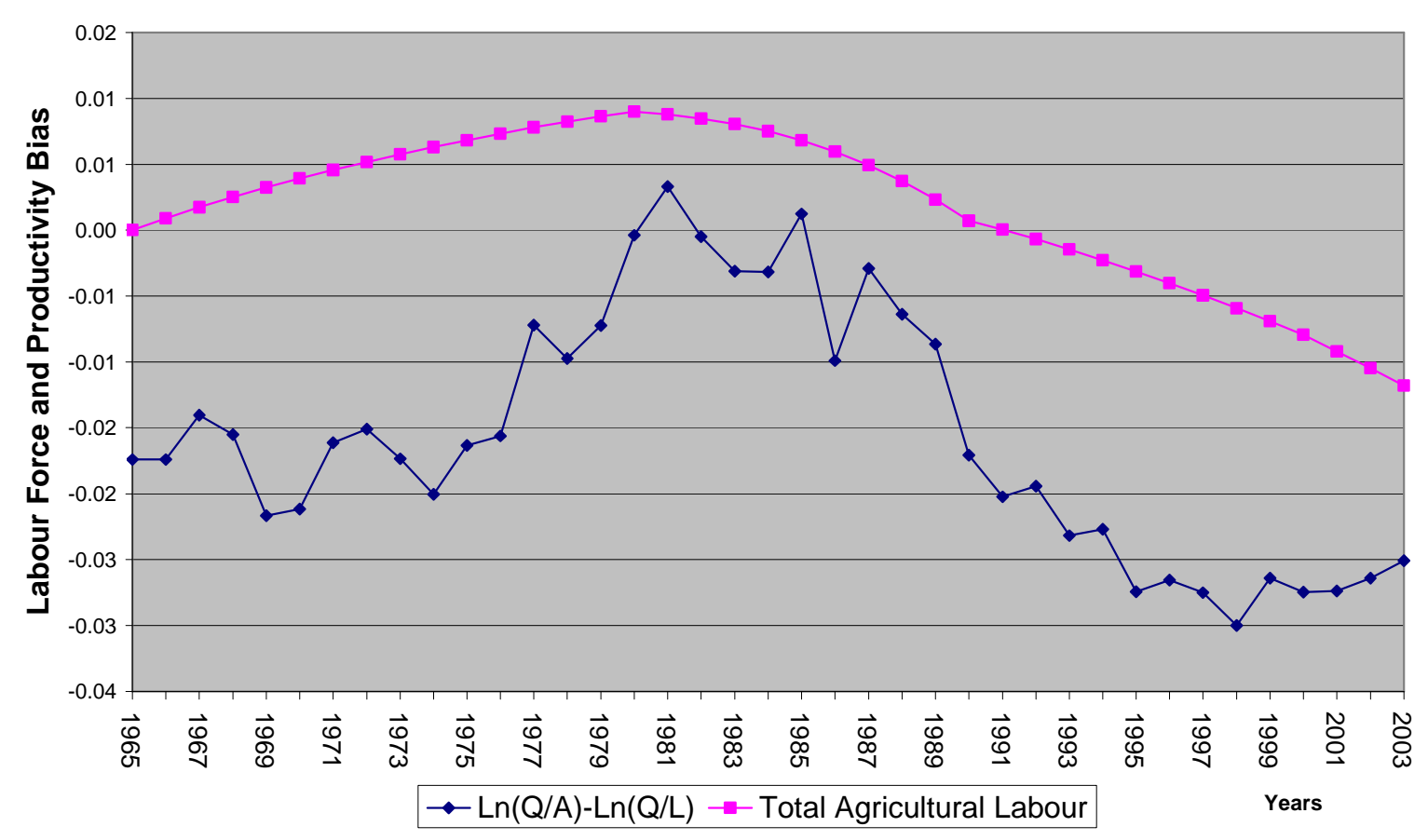

\subsection{Total Factor Productivity: Tornqvist and Malmquist Indices}

The Tornqvist-Thiel discrete approximation of the Divisia input index for the change from period $\mathrm{t}-1$ to period $\mathrm{t}$ is expressed as:

$$
\text { X }=\frac{1}{2} \sum_{j}\left(C_{j t}+C_{j t-1}\right) \ln \left(\frac{X_{j t}}{X_{j t-1}}\right)
$$

which is the sum over all inputs of the logarithms of the ratios of the input levels in the two periods, weighted by the shares in total cost. The weights are an arithmetic average of the two periods and adjust each year. The current price series are used for the weights and the constant price series for the indices themselves. Since the indices are ratios the constant price elements cancel out to give quantity ratios.

Fortunately there are very recent estimates of TFP for both the DCs and LDCs, but whereas there is good data for the EU and other OECD countries, the data for the LDCs is confined to the basic FAO (2005) statistics. Apart from inaccurate data, the problem in 
calculating TFP from the FAO data is that the coverage is only of output and input quantities. There are no data on prices and indeed inputs like land and labour may have no market prices. Hence, it is not possible to calculate shares of inputs in total costs to use as weights to aggregate the inputs, as is required for the construction of TFPs using accounting, or index number techniques. ${ }^{15}$ This difficulty has led to widespread use of programming techniques, such as data envelopment analysis (DEA), which leads to the Malmquist TFP index.

However, one problem with the programming approach, when applied to inter-country comparisons, is choosing the sample. Since the Malmquist index is constructed by comparing each observation with the best practice frontier that is determined from all the observations, the index for each country is dependent on the peers that are included in the analysis. Thus, the choice of the peer group changes MFP measurement for each country in the Malmquist framework, whereas it does not in index number approaches.

The extent of the disparities between studies is huge and mainly attributable to the choice of peers, as the examples in Table 8 show. The range from $1.3 \%$ to $-4.9 \%$ for Ivory Coast, $2.3 \%$ to $-4.1 \%$ for Turkey and $3.3 \%$ to $-7.5 \%$ for South Korea is enough to suggest that something is amiss. Experiments suggest that the peer group is the key factor and with identical data and methods, Piesse et al. (1998) get results for Turkey of $-1.3 \%$ and $-4.1 \%$, just by changing the peers.

Table 6: MFP Growth Rates from Different Studies, for Three Countries.

\begin{tabular}{|c|c|c|c|c|c|c|}
\hline $\begin{array}{c}\text { Countries } \\
\text { Ivory Coast }\end{array}$ & Arnade & $\begin{array}{l}\text { Fulginiti \& Perrin } \\
-4.9 \%\end{array}$ & $\begin{array}{c}\text { Suhariyanto et al } \\
0.63 \%\end{array}$ & Piesse et al & $\begin{array}{c}\text { Thirtle et al } \\
1.3 \%\end{array}$ & Trueblood \\
\hline Turkey & $-1.8 \%$ & $2.3 \%$ & & $-1.3 \%^{1}-4.1 \%^{2}$ & & $-3.0 \%$ \\
\hline South Korea & -2.8 & $-7.5 \%$ & $3.3 \%$ & & & \\
\hline
\end{tabular}

Arnade (1998) Worldwide sample of 70 countries, with a developed country bias, from 1961-93.

Fulginiti and Perrin (1997) Disparate group of 18 LDCs, from 1961-85.

Suhariyanto et al (2001) African sample of 47 countries, from 1961-91. Asian sample of 18 countries, 1961-96. Piesse et al. (1998). ${ }^{1}$ Turkey with Asia \& the Middle East. ${ }^{2}$ Turkey with the EU \& potential entrants, 1961-96.

Thirtle et al. (1995). 22 countries in SSA, from 1971-86

Trueblood (1996) Worldwide sample of 78 countries, with a developed country bias, from 1961- 1993.

From: Thirtle et al. (2003)

There is no obvious solution to this problem since the conventional wisdom is that homogeneity is a crucial requirement, since like must be compared with like (Fare et al., 1994, Lovell, 1993). But, changing the group causes the disparities shown above and the

\footnotetext{
${ }^{15}$ The indices vary, with many countries still using the Laspeyres index, which is base period weighted. Others have moved on to what are known as superlative indices. Hence, the USDA now uses the Tornqvist-Theil index and the UK uses Fisher's ideal index.
} 
alternative is to maximise the number of countries, which also maximises the chances of comparing apples and oranges.

In summary, this methodology is sensitive to the set of countries included in the comparison and the number of input and output groups (level of aggregation) in the model. Coelli and Rao (2005) fitted the Malmquist to all available countries and were criticised for the unreasonable sizes of some input share estimates and some of the estimated growth rates. The most recent Malmquist by Ludena et al. (2007) used this method to estimate agricultural productivity growth for 116 countries, finding that average annual agricultural TFP growth increased from $0.6 \%$ to $1.29 \%$ between 1961-1980 and 1981-2000. Thus, the TFPs calculated in this manner show an increase rather than a decline in productivity.

The recent estimates that are reported next owe a debt to Avilla and Evenson (2007), who tackled the lack of data for share weights by applying shares from Brazil and India to all the other LDCs. They apply the share weights calculated for India to Africa and Asia and those for Brazil for Latin American and the middle income countries. Fuglie (2008) extends this by including China, Indonesia, Japan, the UK and the USA as sources of shares, so that the allocation is slightly less crude. For example, the estimates for Brazil were applied to Latin American and Caribbean countries, North African and Middle Eastern countries, and South Africa. The estimates for India were applied to other countries in South Asia as well as countries in Sub-Saharan Africa other than South Africa. The US shares were used for the former Soviet Union countries and the 1967-90 UK shares (from Thirtle and Bottomley, 1992) were used for all of Europe except the USSR. Note too that the Tornqvist-Theil index in equation 1) has time subscripts. But in Fuglie (2008) the shares are constant, so the underlying translog function is reduced to the Cobb Douglas. Whilst there is no doubt that this is a very crude approach, it may be better than the Malmquist index, which few of us trust for these comparisons, for the reasons given above. ${ }^{16}$

Fuglie finds no evidence of a general slowdown in TFP growth from 1970-2006. Indeed, for the world TFP up to 1989 grew at $0.87 \%$ per annum and from 1990 at $1.56 \%$ per annum. He also notes that yield (maize, rice and wheat) growth fell from $2.29 \%$ pa to $1.35 \%$ pa and output per hectare from $1.96 \%$ to $1.95 \%$, while labour productivity growth rose from $1.25 \%$ pa to $1.51 \%$. The major finding that reconciles these results is that it in input growth

\footnotetext{
${ }^{16}$ It is wildly inaccurate to use US shares for the FSU countries and ancient UK shares for countries as different as the Netherlands and Greece, but there is better data that would allow this approach to be developed. We had hoped that by cunning estimation of the Cobb Douglas (with constant returns imposed, so the coefficients could be interpreted as shares) and with panels with different periods, we could get shares that changed over time and hence arrive at the weights for a quasi-Tornqvist index. However, panel data estimation on this poor data has so far given only very messy results.
} 
that has declined, as in the extreme case of the UK, where it was negative. TFP growth largely offset decelerating input growth to keep the real output of global agriculture growing at about $2 \%$ per year since the 1960 s, but there was a slowdown in the growth of agricultural investment. This is an important finding and explains why the supply response to the food price crisis was so strong. Lack of investment on farms can be corrected far more quickly than lack of new technology, where we know the R\&D and diffusion lags run into double figures.

Fuglie's results show that there is no general decline. Indeed, there is TFP growth that offsets the decline in inputs and keeps output rising. His results are reported by decade. For the DCs and the LDCs, USSR, the FSU, Eastern Europe, LAC, NE Asia, China, SE Asia and N America, TFP growth in the 1990s and since 2000 was greater than in the 1980, which was an improvement on the 1970s. For Western Europe, Oceania and SSA the 1990 was an improvement on the 1980s, but since 2000 is lower than the 1980s. For the MENA, South Asia and India, both recent periods show lower growth than the 1980s. On average then, his results are heavily biased in favour of growth rather than decline.

Since there is evidence that yield growth may have declined and even labour productivity growth has slowed, it is important to note that TFP is different exactly because it takes account of the land and labour substitutes that are modern intermediate and capital good inputs. Less capital investment and chemicals will increase TFP just as well as more output or higher land or labour productivities.

But is there any reason to suppose that Fuglie's results are biased in this direction? One comparison that can be made is between his Western Europe results and those of Ball (2003) who has TFPs for eleven EU countries, using Eurostat data to construct TornqvistTheil TFPs. For the 1980s Fuglie has growth of $1.65 \%$ and Ball has $1.65 \%$ too, which is reassuring, but in the 1990s, Fuglie has a rise to $1.97 \%$, while Ball has a minute fall to $1.64 \%$. Figure 13 shows TFP growth for the EU counties and shows that the UK is not at all typical. Although EU yield growth may be falling, TFP does not appear to fall, or for that matter to rise. 
Figure 13: TFP Growth in the EU

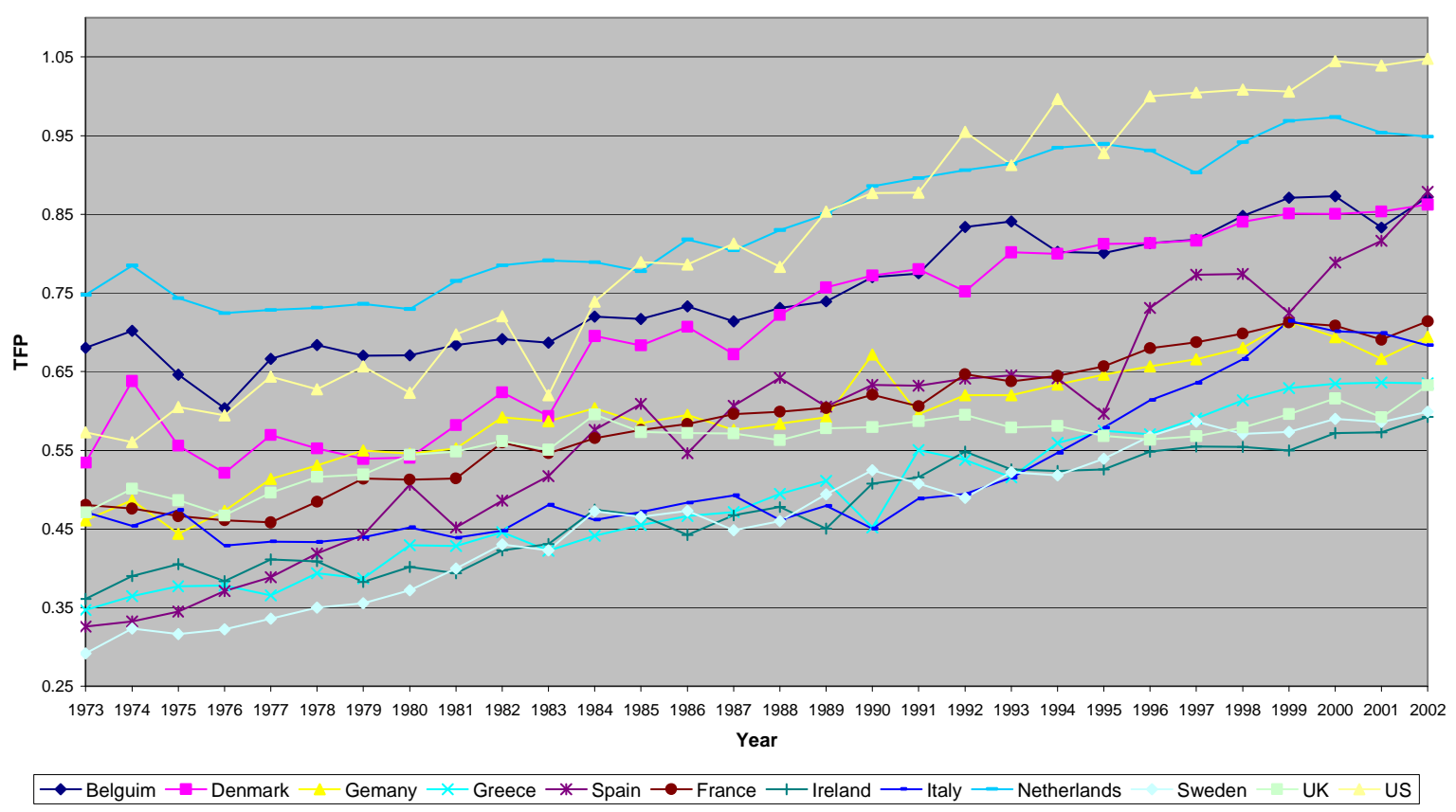

This suggests a tendency for the geometric indices to give higher changes in growth than the Tornqvist-Theil index, but when technical change is biased, this is likely to happen. The issue of how TFP should be measured when there are biases was raised by Murgai (2003), who won the IAAE prize for best paper. The effect, when there is a pronounced labour saving bias, was investigated by Bailey, Irz and Balcombe (2004), who found that it did affect TFP measurement. Indeed, they showed that basically because the share of labour (the most rapidly falling input) fell by half, its effect on TFP growth was reduced. If labour's share were held constant, as it is in Fuglie's geometric index, then the decline in UK TFP shown in Figure 4 no longer occurs. This does serve as a warning on how sensitive to shares the TFP indices are.

The earlier (but still unpublished) contribution of Avila and Evenson (forthcoming) is less broad in coverage and less unequivocal in its findings. They report that TFP has risen since the pre 1980 period, at least to 2001 , for LAC (1.39\% to $2.31 \%$ ), Asia (1.92\% to $2.50 \%$ ) and Africa $1.20 \%$ to $1.68 \%$ ). However, sub regions give a less clear outcome, as within LAC, Central America declined from $2.17 \%$ to $1.32 \%$ and the Caribbean from $2.03 \%$ to $0.90 \%$. In Asia, the Middle East was down from $2.93 \%$ to $0.98 \%$ and SE Asia from $2.37 \%$ to $0.61 \%$. In Africa, Central Africa was down from $1.09 \%$ to $0.68 \%$ and Southern Africa from $1.80 \%$ to $0.79 \%$. So, again there is considerable variation, but with growth dominating decline. 
The Malmquist approach has not been abandoned and may indeed be no worse than the geometric indices just covered. In one aspect it is clearly superior. Whereas the index number approach is equivalent to an OLS regression production function (or mean response function) in that it assumes that any variation is random error, the Malmquist index is derived from the programming approach that defines an efficiency frontier. Then, movement of the frontier is technological change, whereas a change in the distance of an observation from the frontier is efficiency change. This distinction has important connotations since efficiency changes are not dependent on new technology. They may be quicker, but will not continue without the frontier moving.

Ludena et al. (2007) use this method to estimate agricultural productivity growth for 116 countries, and found that average annual agricultural TFP growth increased from $0.6 \%$ to $1.29 \%$ between 1961-1980 and 1981-2000. These positive results are used to forecast optimistic increases in productivity to 2040. Most recently, Nin Pratt and Yu (2008) have produced estimates concentrating on SSA and using the Malquist, but with shares constrained to stay within bounds derived from Avila and Evenson (2007). This is an interesting approach, but it may combine the best or the worst of both approaches. The results in Figure 14 show that TFP was declining in SSA until the mid 1980s, after which there is a dramatic recovery. Up to 1985 , TFP declined at $1.67 \%$ per annum and after that date grew at $1.73 \%$, with a further improvement to $1.83 \%$ in the 1990s. This is in keeping with earlier Malmquist results, such as Lusigi and Thirtle (1997), but is the technique inclined to have an upward bias?

Figure 14. Index of cumulative TFP growth in SSA $(1961=1)$

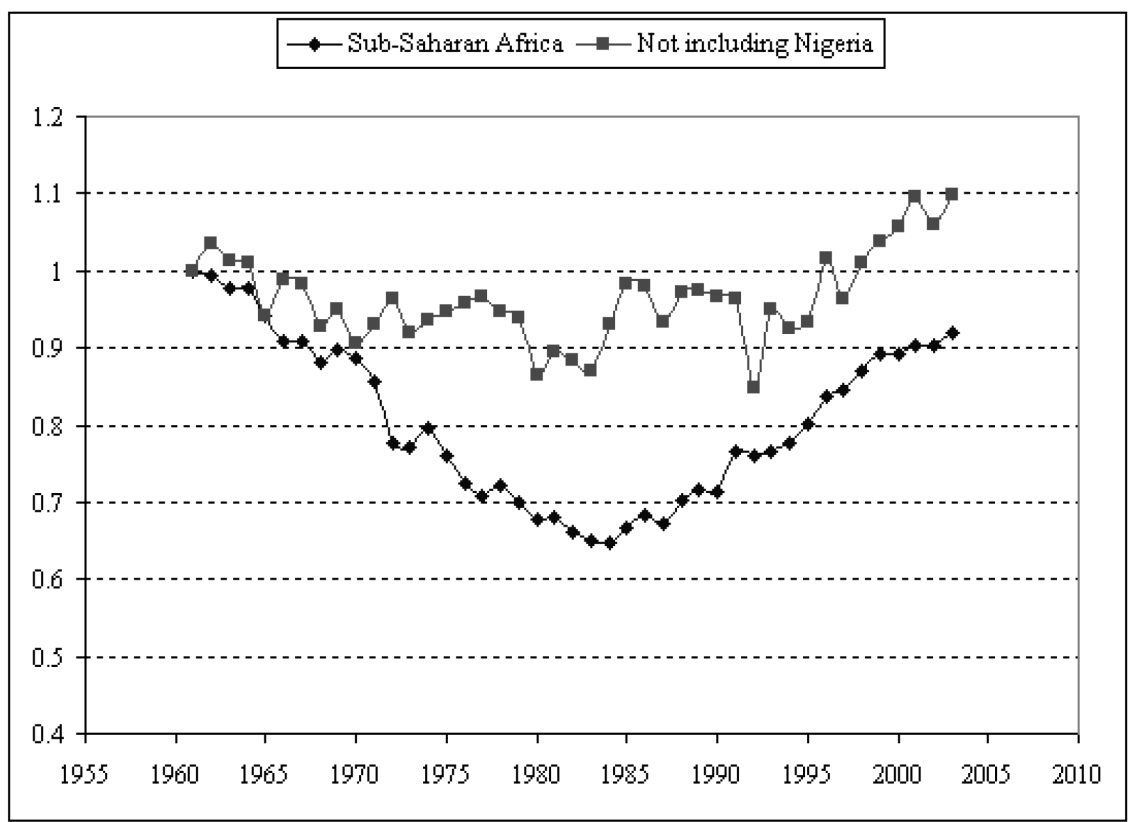


Figure 15 shows TFP growth in SSA relative to Asia and Latin America. The conflict with the geometric index results is clear, in that only Latin America had positive growth prior to 1983 , and even that was at less than $1 \%$. Then, all the regions improve in the 1984-93 period and all improve again from 1994-2003. This blanket monotonicity is a little disconcerting, but to date there is no obvious reason to more than suspect a bias.

Figure 15. Average TFP growth rate of SSA's agriculture in different periods compared with TFP growth in other regions

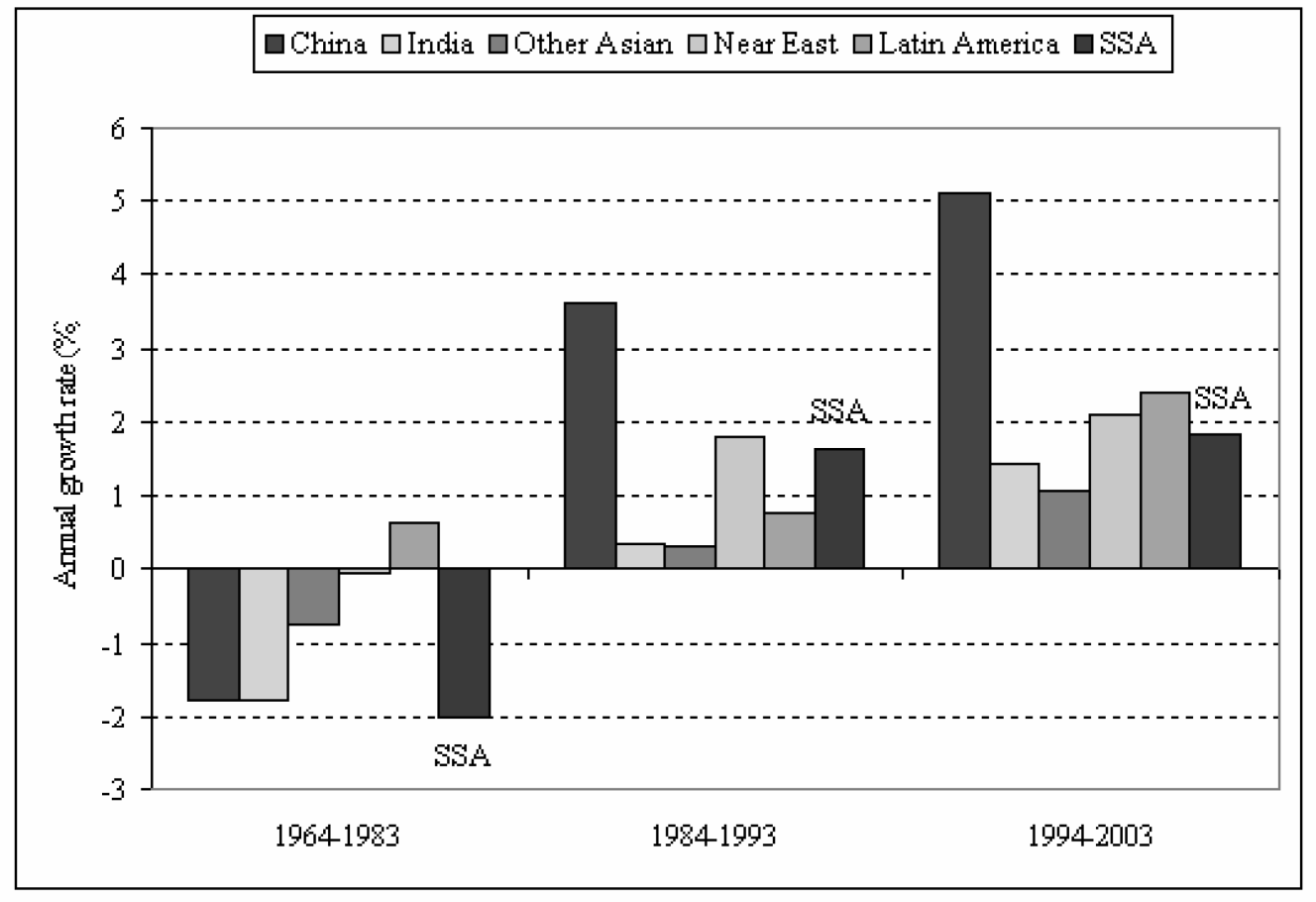

The improvement in SSA is partly due to better agricultural practices, but the authors stress that almost all the improvement is due to efficiency increases rather than technological change. They suggest that many countries in SSA have better policies, better governance, improved institutions and infrastructure, which has taken them closer to the technological frontier. However, the frontier is not moving outwards, so the R\&D systems are not creating better technologies for the future. Thus, the prospects are limited as the efficiency gains will cease if the frontier is static. So Nin Pratt takes a pessimistic view in this paper to counterbalance the optimism of Ludena at al. (2007).

The above review is sufficient to show that there is no consistent evidence of a decline in TFP. The methods may be imperfect, but all suggest growth rather than decline when using these broad sets of data. Thus, the evidence of decline is confined to TFP studies of individual countries, such as the UK, which turns out to be atypical even of the rest of the EU. However, the evidence on yields was more dismal and that on labour productivity did not 
feature gains, despite the turning point argument that labour productivity must improve when agricultural employment starts to decline. Gains in the transitional countries may be counterbalanced by slower labour productivity growth in the most advanced countries.

\section{Prospects for the Future: Technologies, Energy, Oil, Biofuels and Other Factors}

This review above is still deficient in several directions which cannot be considered in any detail. So far no attempt has been made to more than touch on the scientific possibilities that will determine the ease with which technical progress can be made. There is a background view that the green revolution technology has reached a stage of maturity at which all the easy gains have been made and further yield growth will be slower and more costly and difficult (Maredia and Byerlee (2000). Ruttan (2002) is pessimistic on growth with sustainability in agriculture. He cites soil degradation, water shortages, increasing pest control problems and climate change, rating pests as the biggest problem to overcome.

In the LDCs, farmers in those countries which have not yet acquired the capacity to invent or adapt technology specific to their resource endowments will continue to find it difficult to respond to the growth of domestic or international demand. The development of research capacity is insurance against the uncertain future and many poor countries do not have it. Evenson and Pingali (2007) investigate the ability of countries to invent or import technologies. They list 87 countries by modern variety adoption rates, showing that twelve countries had no green revolution. All were failed states and all were small, ten were African and most had suffered civil conflict. Forty-four had underperformed, of which all were small and more than half (28) were African, leaving only thirty one that had performed well.

Avila and Evenson (2007) follow Jones (2000) in distinguishing between countries that have developed the capacity to invent and innovate, as opposed to those that are striving to master the internationally available technology. They construct an invention/innovation (II) capital index and a technology-mastery (TM) capital index, showing that some countries have actually regressed and that African states do poorly even at TM.

In the DCs the problem is different. The rate of increase of yields is falling and the share of maintenance research is rising, especially where the greatest gains have been made (Plucknet and Smith 1986). The cost of science has increased rapidly and there are now diminishing returns to both public and private $R \& D$ investment, despite the public good aspect of technology. Thus, there is a growing divide (Pardey et al, 2006) in agricultural R\&D between the poor countries, especially the small ones, who do not spend enough to enter 
the technology market and the rich countries that are spending so much they face diminishing returns.

Ruttan (2002) applies this argument to both public and private agricultural $R \& D$, but in the DCs, as public R\&D has slowed, private has increased, so that private now dominates in countries like the UK and the USA. This switch, which accompanied the advent of biotechnology is partly the result of the huge costs, which made small national agricultural research systems (NARS) too small to compete with companies like Monsanto and also to the development of genetic markers, which have made biological materials much more patentable. ${ }^{17}$ One result of this change is that agricultural R\&D is now truly global. Thirtle et al. (1991) found that ICI did $90 \%$ of its R\&D in the UK, which was less than $10 \%$ of its market, simply because it is a British company, with a long history. In 1930, their Jealott's Hill facility was the largest agricultural research station in the UK with a staff of 36 . The other $10 \%$ of ICIs R\&D was performed in California, again not because of markets, but because of the concentration of skilled researchers. So, any attempt to attribute technology generation to just NARS R\&D is now doomed. Nor was private sector R\&D the sole province of the DCs. Even in SSA, Thirtle and Echiverria (1994) found considerable private activity.

\subsection{Biotechnology and Genetically Modified Crops}

Biotechnology and especially GM crops are the new major technological breakthrough (Ruttan, 2002), but as the technology is private sector it is developed in and mainly for rich countries. The two dominant traits are pest resistance (from Bacillus thuriegensis, or Bt) and herbicide tolerance. Evenson and Pingali (2007) show that the USA has the highest gains from GM and Europe has the lowest. This is partly due to crop mix, but the EU does grow substantial quantities of oilseed rape (canola) and eschewing GM must be a part cause of the difference in yield grow between North America and Europe. More damaging is the way the EU has influenced the LDCs, by threatening import bans. This has slowed the adoption of the limited range of GM crops available, perhaps especially in SSA, but there are exceptions.

In KwaZulu Natal, Bt cotton was in use by smallholders as early as 1999 and now genetically modified herbicide tolerant white maize is being used in minimum tillage systems. Roundup is used to kill the weeds so there is no deep ploughing, which rehabilitates the oxen, which are used for shallow ploughing for planting and this cuts soil erosion substantially

\footnotetext{
${ }^{17}$ Wright et al. (2007) cover the incentive effects of patents, the need for intellectual property rights (IPRs) and also the uneasy trade off between incentives and free access to maximise spillovers. Srinivasan and Thirtle (2003) find evidence that IPRs do increase R\&D investment. Herdt et al. (2007) review the possible impacts of biotechnology and discuss the link between genetic markers and the oligopolistic nature of the industry.
} 
(Gouse, Piesse and Thirtle, 2006). Thus, what was developed as a labour saving technology has become a soil saving technology. ${ }^{18}$ The cotton and maize varieties are from Monsanto in the USA, but other biotechnology developments, such as striga (witchweed) control in maize are indigenously developed. However, GM has yet to have the impact of the green revolution varieties in the LDCs

\subsection{Energy Efficient technologies?}

The problems of low $R \& D$ expenditures and slowing productivity are closely linked to the prices of oil, fuel and fertiliser. The dominant forces in agriculture in the developed countries in the $20^{\text {th }}$ century were the fertiliser revolution and the mechanical revolution. Thus, it is a fair generalisation to say that almost all the agricultural technologies available are energy intensive. If energy is to remain expensive, they are not appropriate, but it is hard to see may energy-efficient alternatives.

How can yield growth be maintained with lower energy inputs, if artificial nitrogen becomes increasingly expensive? How can agriculture reduce the pollution it causes, manage with less irrigation water, produce less methane and less nitrogen runoff? There are some exceptions that head in the right direction, one of which must be better targeting. Satellite technology is now used to determine exactly the inputs needed in advanced country farming. In poor countries, drip irrigation (which is labour intensive) increases employment and saves scarce water. Fertiliser and pesticide can be targeted at individual plants. This was done in sugar beet in 1990s (Thirtle, 1999) when pelleting of seeds allowed each one to be encapsulated with its own supply of plant protection chemicals and fertiliser. This reduces input use and pollution impressively and the same approach is spreading to LDCs with similar target of individual plants with their own input doses, by using new ideas like small briquettes of urea. Using new technologies to improve old techniques is also productive.

\subsection{Agriculture and Oil}

Agriculture is becoming a part of the massive energy industry. The oil price is low again now, but only because of the economic slowdown. As soon as growth begins again we have to reckon on substantial demand for ethanol and biodiesel. This is both a threat to LDC food supplies and an opportunity for LDCs to respond to energy demand. The price spike of 2008 produced a substantial supply response, even in SSA, at least until the effect is viewed at country level, as then it transpires that South African commercial farmers were largely

\footnotetext{
${ }^{18}$ Ruttan (2002) is unsure as to the future factor saving biases in SSA. He says "even relatively land abundant countries, in Sub-Saharan Africa for example, will because of failure to develop a strong inter-sector labour market, end up following the East Asian biological technology path".
} 
responsible. The limited evidence available for SSA suggests that just as consumers were protected from the worst of the price increases by very poor price transmission to most countries and areas, this also meant that the incentives to local producers were minimal.

\subsection{Sustainability and Climate Change}

Ruttan's (2002) take on sustainability preceded the rising level of concern over emissions and climate change. Any view of future productivity growth has to take account of the environmental costs that contribute to climate change. Worse still, agriculture will have to deal with increasing climatic variability and loss of land as sea level rises.

\subsection{Other Factors}

The region which seems to have improved its productivity, rather than faring worse in recent years is SSA. The last section suggested that this was attributable to efficiency improvements rather than technical progress. This is stressed by Nin Pratt et al. (2008) who attribute the changes in SSA to non-technology factors, particularly better policies. This is one aspect, along with some improvements in incentives and institutions, in governance and in infrastructure. This has always been the case that the most backward countries can thrive on efficiency gains. ${ }^{19}$ It is the more successful counties in Asia, who have already reaped these rewards that have to worry about the slowing of technical possibilities.

\section{Conclusions}

This paper considers the impact of the "productivity slowdown" on the prospects for productivity growth in the developing countries. It questions the existence of such a slowdown, pointing out that though yield growth has slowed on aggregate, labour productivity growth varies and TFP has improved in most regions. To the extent that there is a break in the trends for all measures, it comes in the mid 1980s. The paper presents evidence that since then, new FAO data shows that the long fall in food prices practically ceased. The UK is used as the extreme example of the changes that affected the DCs. Mrs Thatcher's R\&D cuts began in 1982 and by 1985 TFP and yield growth practically ceased. However, much of the cause was lack of take up by farmers, due to poor margins, rather than lack of technology. Some of the same malaise is noted in the USA, but less severe and in much of Europe there was little sign of declining TFPs.

The paper stresses the interactions, between DCs and LDCs, between public and private $R \& D$ and between sectors, as countries such as China and India have reached the

\footnotetext{
${ }^{19}$ Several of the papers in Myint (1971) make the point that the poorest countries are so far from the efficiency frontier that dynamics are not needed to analyse their development process.
} 
transitional stage where industry and urbanisation has taken the leading role in the growth process. Similarly, agriculture not only reacts to the oil price because of fertiliser, fuel and transport costs, but it has become a part of the energy industry, due to the rapidly growing demand for biofuels. This is both a challenge and opportunity for the LDCs, as well as a threat.

Although the food price crisis generated all sorts of pleas for increased funding, the economic downturn will mean that few donors will increase funding for public R\&D. So, Monsanto and the rest of the multinationals will become increasingly important. Thus, the gene revolution will lack the public sector agenda that led to the green revolution having a poverty focus. Private companies needs must operate where profits can be made and this precludes the least resource rich, most marginal and distant farming areas. The prospects for growth may well be better than the prospects for poverty reduction. This is unfortunate, as in the past, agricultural productivity seems to be an important source of poverty reduction as it helps the rural poor increase their welfare directly and also helps the urban poor by lowering food prices. Perhaps the reform of the CGIAR may help alleviate this potential loss by extending the role its institutions played in spreading the green revolution (Pingali and Kelly, 2007). This divisive tendency will be exacerbated by climate change, as both higher temperatures and a rise in sea level will hit tropical LDCs hardest.

Against this gloom, there is the fact that SSA is finally making progress, so the some of the poorest are likely to benefit. Higher up the income scale, more countries are reaching the turning point in the structural transformation, when agricultural labour productivity rises as a result of labour being withdrawn from agriculture. Agriculture has to provide both food and labour for industrialisation. ${ }^{20}$ If it succeeds it transforms itself and the country joins the ranks of the industrialised, urbanised group, with greater prosperity. If it fails, it holds back industrialisation and urbanisation and slows the development process. So, for LDCs at all levels, there are prospects of productivity growth, but those with very little technological capacity will be disadvantaged. Increasing labour productivity is usually sufficient to also mean increasing TFP, but it is increasing yields that the world will need to meet both food and energy demand. This will re-emerge as the recession eases and China and India resume their rapid transformations.

\footnotetext{
${ }^{20}$ This has always been the message of economic history. The means differ, from slow, gradual transition in Britain, to greater levels of state coercion in Japan and Europe, to the human costs of Stalin's First Five Year Plan. (Gershenkron, 1962)
} 
The lead and indeed the contribution of the richest countries may be less now than it was in the 1960s and 1970s, but this may be a historic inevitability. Jones (2000a, 2002) pointed out that the USA was well above its long term historical growth path in the post WWII period and that this could not be maintained. There are limits to how high research intensities and the proportion of the population going to college can rise. These transformations and also the globalisation of the world economy were one-off events which will not be repeated by the DCs. This is true and it is the transitional countries beginning to follow that same path that will power the growth process in the next decades. Hopefully, the growth paths will not be as environmentally damaging as industrialisation in Europe and the USA, or it is climate change that will take us to the classical stationary state. 


\section{References}

Adusei E and Norton G (1990), The Magnitude of Agricultural Maintenance Research in the USA, Journal of Production Agriculture, 3:1, 1-6

Alston J, Beddow J and Pardey P (2008), Agricultural Research, Productivity, and Food Commodity Prices

Alston, J, Chan-Kang C, Marra M, Pardey P and Wyatt T (2000), Meta-analysis of Rates of Return to Agricultural R\&D: Ex Pede Herculem?, Research Report No. 113, Washington DC: IFPRI. June

Alston J, Pardey P and Smith V (1999), Paying for Agricultural Productivity, Johns Hopkins University Press, Baltimore

Arnade C (1998), Using a Programming Approach to Measure International Agricultural Efficiency and Productivity, Journal of Agricultural Economics, 49:1, 67-84

Avila, A.F., Evenson, R.E. (forthcoming). "Total factor productivity growth in agriculture: The role of technological capital”. In: Evenson, R.E., Pingali, P. (Eds.), Handbook of Agricultural Economics, vol. 4, Elsevier Science, Amsterdam. In press.

Bailey A, Irz X, Balcombe K (2004), Measuring productivity growth when technological change is biased-a new index and an application to UK agriculture, Agricultural Economics, 31:2-3, 285-95

Ball V E (2003), Levels of Farm Sector Productivity: An International Comparison, paper presented to DEFRA, UK

Beintema N and Stads G (2006), Agricultural R\&D in Sub-Saharan Africa: An Era of Stagnation. ASTI Background Paper, IFPRI. Washington, DC.

Beintema N and Stads G (2008), Measuring agricultural R\&D investments: A revised global picture, IFPRI. Washington, DC.

Blakeslee L (1987), Measuring the Requirements and Benefits of Productivity Maintenance Research, in: Evaluating Agricultural Research and Productivity, Proceedings of a Symposium, Atlanta, Georgia, Miscellaneous Publication 52-1987 Minnesota Agricultural Experiment Station, University of Minnesota, St Paul, MN

Carroll L (1872), Through the Looking Class, Penguin, London

Cochrane W (1979), The Development of American Agriculture: A Historical Analysis, University of Minnesota Press

Coelli T and Rao P (2005), Total factor productivity growth in agriculture: A Malmquist index analysis of 93 countries, 1980-2000. Agricultural Economics 32: s1, 115-34

DEFRA (2006) Agriculture in the United Kingdom, HMSO, Norwich 
Evenson R E and Gollin D (2007), Contributions of National Agricultural Research Systems to Crop Productivity, Chapter 46 in Handbook of Agricultural Economics, Volume 3, Robert Evenson and Pingali (eds), Elsevier Science

Evenson R and Kislev Y (1975), Agricultural Research and Productivity, Yale University Press, New Haven

Evenson R, Waggoner P and Ruttan V (1979), Economic Benefits from Research: An Example from Agriculture, Science, 205, 1101-1107

Evenson R (2001), Economic impacts of agricultural research and extension, Chapter 11 in Handbook of Agricultural Economics, Volume 1, Bruce Gardner and Gordon Rausser (eds), Elsevier Science

Evenson R and Pingali P (2007), Overview, Handbook of Agricultural Economics, Volume 3, Robert Evenson and Pingali (eds), Elsevier Science

FAO, FAOSTAT, Statistical Databases on CD Rom, FAO, Rome.

Fuglie K (2008), Is a slowdown in agricultural productivity growth contributing to the rise in commodity prices? Agricultural Economics, 39, supplement, 431-441

Fulginiti L and Perrin R (1997), LDC Agriculture: Nonparametric Malmquist Productivity Index, Journal of Development Economics, 53, 373-90

Gershenkron A (1962), Economic Backwardness in Historical Perspective, Belnap Press, Cambridge, Mass

Gouse M, Piesse J and Thirtle C (2006), Output and Labour Effects of GM Maize and Minimum Tillage in a Communal Area of KwaZulu Natal, Journal of Development Perspectives, $2: 2$

Grigg D (1989), English Agriculture: An Historical Perspective, Blackwell, Oxford

Herdt R and Toenniessen G (2007), Plant Biotechnology for Developing Countries, Chapter 50 in Handbook of Agricultural Economics, Volume 3, Robert Evenson and Pingali (eds), Elsevier Science

Holderness B (1985), British Agriculture since 1945, Manchester University Press, Manchester

Hayami Y and Ruttan V (1971), Agricultural Development: An International Perspective, Baltimore: Johns Hopkins University Press

Hayami Y and Ruttan V (1985), Agricultural Development: An International Perspective, revised edition, Baltimore: Johns Hopkins University Press

Huffman W and Evenson R (1992), Contribution of Public and Private Science and Technology to US Agricultural Productivity, American Journal of Agricultural Economics 74:3, 751-6

Jones C (2000), Introduction to Economic Growth, $2^{\text {nd }}$ edition, Norton, New York 
Jones C (2000a), The Upcoming Slowdown in US Economic Growth, paper presented at the ASSA meetings, Chicago

Jones C (2002), Sources of Economic Growth in a World of Ideas, American Economic Review, 92, 220-39

Lucas R (1988), On The Mechanics of Economic Development, Journal of Monetary Economics, 22, 3-42

Ludena C, Hertel T, Preckel P, Foster K and Nin A (2007) Productivity growth and convergence in crop, ruminant, and non-ruminant production: Measurement and forecasts. Agricultural Economics 37:1, 1-17

Lusigi A. and Thirtle C (1997), Total Factor Productivity and the Effects of R\&D in African Agriculture, Journal of International Development, 9:4, 529-38

Maredia M and Byerlee D (2000), Efficiency of research investments in the presence of international spillovers: wheat research in developing countries, Agricultural Economics, 22, 1-16

Murgai R (2003), the green revolution and the productivity paradox: Evidence from the Indian Punjab, paper presented at the IAAE conference, Berlin

Myint H (1971) Economic Theory and the Underdeveloped Counties, Oxford University Press, London

Nin Pratt A and Yu B (2008), An Updated Look at the Recovery of Agricultural Productivity in Sub-Saharan Africa, IFPRI Discussion Paper 00787

Quah D (1997), Empirics for Growth and Distribution: Stratification, Polarization and Convergence Clubs, Centre for Economic Policy Research, Discussion Paper No.1586, London

Pardey P, Beintema N, Dehmer S and Wood S (2006), Agricultural Research A Growing Global Divide? IFPRI, Washington DC.

Piesse J. and Thirtle C (1997), Sector Level Efficiency and Productivity in Hungarian Primary, Secondary and Tertiary Industries, 1985-91, Eastern European Economics, 35:4, 5-39

Piesse J and Thirtle C (2009), Three Bubbles and a Panic: An Explanatory Review of the Food Commodity Price Spikes of 2008, Food Policy, 34:2, forthcoming

Piesse J Suhariyanto K and Thirtle C (1998), International Agricultural Productivity Comparisons: Turkey, the LDCs, Neighbouring Countries and the EU, paper presented at the conference on Science and Research Policy in Turkish Agriculture, Agricultural Economics Research Institute, Ankara, Turkey

Pingali P and Kelley T (2007), The Role of International Agricultural Research in Contributing to Global Food Security and Poverty Alleviation: the Case of the CGIAR, Chapter 45 in Handbook of Agricultural Economics, Volume 3, Robert Evenson and Pingali (eds), Elsevier Science 
Plucknett D and Smith N (1986). Sustaining Agricultural Yields, Bioscience. 36:1, 40-45

Pray C E, Fuglie K O and Johnson D N (2007), Private Agricultural Research, Chapter 49 in Handbook of Agricultural Economics, Volume 3, Robert Evenson and Pingali (eds), Elsevier Science

Romer P (1986), Increasing Returns and Long-Run Growth, Journal of Political Economy, 94, 1002-37

Romer P (1990), Endogenous Technical Change, Journal of Political Economy, 98:5, S71-S102

Ruttan V (2002), Productivity Growth in World Agriculture: Sources and Constraints, Journal of Economic Perspectives, 16(4): 161-184.

Ruttan V and Thirtle C (1989), Induced Technical and Institutional Change in African Agriculture, Journal of International Development, 1:1, 1-45

Sarris A (2008), Agricultural Commodity Markets and Trade: Price Spikes or Trends? Paper presented at a Conference "The Food Crisis" of 2008: Lessons for the Future" Imperial College, Wye Campus, Kent

Schimmelpfennig D and Thirtle C (1999), Research Spillovers Between the European Community and the United States, Contemporary Economic Policy, 19:4, 457-68

Srinivasan, C. and Thirtle, C., Potential Impact of Terminator Technologies: Policy Implications for Developing Countries, Environment and Development Economics, 8, 187-205, January, 2003.

Suhariyanto K, Lusigi A and Thirtle C (2001), Productivity Growth and Convergence in Asian and African Agriculture, Chapter 14 in P Lawrence and C Thirtle (eds), Comparing African and Asian Economic Development, Palgrave, Basingstoke, in collaboration with the ESRC Development Economics Study Group

Thirtle C (1999), Producer Funding of R\&D: Productivity and the Returns to R\&D in British Sugar, 1954-93, Journal of Agricultural Economics, 50:3, 450-67

Thirtle C, Beck H, Palladino P, Upton M and Wise W (1991), Agriculture and food. In: Nicholson, R H, Cunningham C M \& Gummett, P (Eds) Science and technology in the United Kingdom Longman, London

Thirtle C and Bottomley P (1992), Total Factor Productivity in UK Agriculture, 1967-90, Journal of Agricultural Economics, 43:3, 381-400

Thirtle C, Bottomley P, Palladino P and Shimmelpfennig D (1998), The Rise and Fall of Public Sector Plant Breeding in the UK: A Recursive Model of Basic and Applied Research, and Diffusion, Agricultural Economics, 19:1-2, 127-43

Thirtle C and Echeverria R (1994), Privatisation and the Roles of Public and Private Institutions in Agricultural Research in Sub-Saharan Africa, Food Policy, 19:1, 31-44

Thirtle C, Hadley D and Townsend R (1995), A Multilateral Malmquist Productivity Index Approach to explaining Agricultural Growth in Sub-Saharan Africa, Development 
Policy Review, 13, 323-348

Thirtle C, Hadley D and Townsend R (1995), A Multilateral Malmquist Productivity Index Approach to Explaining Agricultural Growth in Sub-Saharan Africa, Development Policy Review, 13:4, 323-48

Thirtle C, Lin L, Holding J and Jenkins L (2004), Explaining the Decline in UK Agricultural Productivity Growth, Journal of Agricultural Economics, 55:2, 343-366

Thirtle C, Lusigi A, Piesse J and Suhariyanto K (2003), Multi-Factor Agricultural Productivity and Convergence in Botswana, 1981- 96, Journal of Development Economics, 71:2, 605-24

Thirtle C, Palladino P and Piesse J (1997), On the Organisation of Agricultural Research in Great Britain, 1945-94: A Quantitative Description and Appraisal of Recent Reforms, Research Policy, 26, 557-76

Thirtle C and Piesse J (2008), Factor Endowments, Biased Technological Change, Wages and Poverty Reduction: Can Genetically Modified Crops Bring a Green Revolution to SSA? International Journal of Biotechnology, 10:2/3, 184-206

Thirtle C and Piesse J (2009), An Explanatory Review of the World Food Commodity Price Events of 2007-8, A Report to the Chief Scientific Advisor, Department for Innovation, Universities and Skills, London

Thirtle C, Townsend R, Amadi J, Lusigi A and van Zyl J (1998), The Rate of Return on Expenditures of the South African Agricultural Research Council, Agrekon, 37:4, 62131

Townsend R and Thirtle C (2001), Is Livestock Research Unproductive? Separating Health Maintenance from Improvement Research, Agricultural Economics, 25:3, 177-89

Trueblood M (1996), An Intercountry Comparison of Agricultural Efficiency and Productivity, $\mathrm{PhD}$ dissertation, University of Minnesota

USDA, (2009) Foreign Agricultural Service. Production, Supply and Distribution Online. U.S. Department of Agriculture, Washington, DC. Downloaded February 1, 2009, from http://www.fas.usda.gov/psdonline/psdHome.aspx.

Wiggins S (1995), Change in African farming systems between the mid-1970s and the mid1980s, Journal of International Development, 7:6, 807-848

World Bank (2008), Agriculture for development, World Development Report, Washington, DC.

World Bank (2007), World Development Indicators, 2007, CD Rom, World Bank, Washington, DC.

Wright B D, Pardey P G, Nottenberg C and Koo B (2007), Agricultural Innovation: Investments and Incentives, Chapter 48 in Handbook of Agricultural Economics, Volume 3, Robert Evenson and Pingali (eds), Elsevier Science 